University of Nebraska - Lincoln

DigitalCommons@University of Nebraska - Lincoln

USDA Systematic Entomology Laboratory

Entomology Collections, Miscellaneous

2009

\title{
The evolution of food preferences in Coccinellidae
}

José Adriano Giorgi

University of Georgia

Natalia J. Vandenberg

USDA-ARS, Systematic Entomology Lab

Joseph V. McHugh

University of Georgia

Juanita A. Forrester

University of Georgia

S. Adam Ślipiński

CSIRO Entomology, Canberra, Australia

See next page for additional authors

Follow this and additional works at: https://digitalcommons.unl.edu/systentomologyusda

Part of the Entomology Commons

Giorgi, José Adriano; Vandenberg, Natalia J.; McHugh, Joseph V.; Forrester, Juanita A.; Ślipiński, S. Adam; Miller, Kelly B.; Shapiro, Lori R.; and Whiting, Michael F., "The evolution of food preferences in Coccinellidae" (2009). USDA Systematic Entomology Laboratory. 8.

https://digitalcommons.unl.edu/systentomologyusda/8

This Article is brought to you for free and open access by the Entomology Collections, Miscellaneous at DigitalCommons@University of Nebraska - Lincoln. It has been accepted for inclusion in USDA Systematic Entomology Laboratory by an authorized administrator of DigitalCommons@University of Nebraska - Lincoln. 


\section{Authors}

José Adriano Giorgi, Natalia J. Vandenberg, Joseph V. McHugh, Juanita A. Forrester, S. Adam Ślipiński, Kelly B. Miller, Lori R. Shapiro, and Michael F. Whiting 


\title{
The evolution of food preferences in Coccinellidae
}

\author{
José Adriano Giorgi ${ }^{\mathrm{a}, *}$, Natalia J. Vandenberg ${ }^{\mathrm{b}}$, Joseph V. McHugh ${ }^{\mathrm{a}}$, Juanita A. Forrester ${ }^{\mathrm{a}}, \mathrm{S}$. Adam Ślipiński ${ }^{\mathrm{c}}$, \\ Kelly B. Miller ${ }^{\mathrm{d}}$, Lori R. Shapiro ${ }^{\mathrm{e}}$, Michael F. Whiting ${ }^{\mathrm{f}}$ \\ a Department of Entomology, University of Georgia, 413 Biological Sciences Building, Athens, GA 30602, USA \\ ${ }^{\mathrm{b}}$ USDA-ARS, Systematic Entomology Lab, c/o National Museum of Natural History, Smithsonian Institution, P.0. Box 37012, MRC-168, Washington, DC 20013, USA \\ ${ }^{\text {c } C S I R O ~ E n t o m o l o g y, ~ G P O ~ B o x ~ 1700, ~ C a n b e r r a, ~ A C T ~ 2601, ~ A u s t r a l i a ~}$ \\ d Department of Biology, University of New Mexico, 167 Castetter Hall, MSC03 2020, Albuquerque, NM 87131, USA \\ e Department of Entomology, The Pennsylvania State University, 509 Ag. Sciences \& Industries Building, University Park, PA 16802, USA \\ ${ }^{\mathrm{f}}$ Department of Biology and M.L. Bean Life Science Museum, 693 Widtsoe Building, Brigham Young University, Provo, UT 84602, USA
}

\section{A R T I C L E I N F O}

Article history:

Received 24 December 2008

Accepted 25 May 2009

Available online 23 June 2009

\section{Keywords:}

Lady beetles

Ladybirds

Ladybugs

Food preference

Prey

Evolution

Trophic shifts

Phylogeny

Coleoptera

Coccinellidae

Cerylonid Series

Cucujoidea

\begin{abstract}
A B S T R A C T
Despite the familiarity and economic significance of Coccinellidae, the family has thus far escaped analysis by rigorous phylogenetic methods. As a result, the internal classification remains unstable and there is no framework with which to interpret evolutionary events within the family. Coccinellids exhibit a wide range of preferred food types spanning kingdoms, and trophic levels. To provide an evolutionary perspective on coccinellid feeding preferences, we performed a phylogenetic analysis of 62 taxa based on the ribosomal nuclear genes $18 \mathrm{~S}$ and 28S. The entire dataset consists of 3957 aligned nucleotide sites, 787 of which are parsimony informative. Bayesian and parsimony analyses were performed. Host preferences were mapped onto the Bayesian tree to infer food preference transitions. Our results indicate that the ancestral feeding condition for Coccinellidae is coccidophagy. From the ancestral condition, there have been at least three transitions to aphidophagy and one transition to leaf-eating phytophagy. A second transition to leaf-eating phytophagy arose within an aphidophagous/pollinivorous clade. The mycophagous condition in Halyziini originated from aphidophagy. Our findings suggest that polyphagy served as an evolutionary stepping stone for primarily predaceous groups to adopt new feeding habits. The analyses recovered a clade comprising Serangiini plus Microweiseini as the sister group to the rest of Coccinellidae. The subfamilies Coccinellinae and Epilachninae are monophyletic; however, Sticholotidinae, Chilocorinae, Scymninae, and Coccidulinae are paraphyletic. Our results do not support the traditional view of phylogenetic relationships among the coccinellid subfamilies. These results indicate that the current classification system poorly reflects the evolution of Coccinellidae and therefore requires revision.
\end{abstract}

(c) 2009 Elsevier Inc. All rights reserved.

\section{Introduction}

Of all the predaceous beetle groups, perhaps the most familiar to non-specialists is the lady beetle family, Coccinellidae. It is widely known that this charismatic group includes many beneficial species that are voracious predators of pestiferous aphids and scale insects. Indeed, the first successful classical biological control effort involved the introduction of the vedalia beetle, Rodolia cardinalis (Mulsant), to control cottony cushion scale, Icerya purchasi Maskell (Heteroptera: Margarodidae), on citrus plants in California during the late 1880s (Caltagirone and Doutt, 1989).

Despite this familiar stereotype of the family, Coccinellidae is far from homogeneous with respect to feeding behavior (Figs. 18 and Table 1 ). While most coccinellids are predaceous, some are

\footnotetext{
* Corresponding author.

E-mail address: coccinellid@gmail.com (J.A. Giorgi).
}

specialists on plant material (e.g., leaves), whereas others feed on fungi (Sutherland and Parrella, 2009). Even among the predaceous coccinellids, feeding preferences vary widely. Most of the preferred prey belong to the hemipteran suborder Sternorrhyncha (aphids, aldelgids, scales, mealybugs, whiteflies, and psyllids) (Hodek and Honěk, 2009; Obrycki et al., 2009), but there are significant deviations from this pattern. Some coccinellid species are known to feed on ants (Hymenoptera: Formicidae) (Harris, 1921; Pope and Lawrence, 1990; Samways et al., 1997; Majerus et al., 2007). Other coccinellid species are specialists on non-insects; for example, all members of the tribe Stethorini prey on tetranychid mites (Biddinger et al., 2009). Thus, the evolution of Coccinellidae includes feeding transitions that cross kingdoms of life (plant, animal, and fungus) and trophic levels (e.g., herbivore and primary carnivore).

'Some feeding behaviors of Coccinellidae are especially interesting given the phylogenetic position of the family. Coccinellidae is part of a monophyletic group, the Cerylonid Series (C.S.), 
which includes seven other families of cucujoid beetles: Alexiidae, Bothrideridae, Cerylonidae, Corylophidae, Discolomatidae, Endomychidae, and Latridiidae (Crowson, 1955; Robertson et al., 2008). C.S. includes approximately 9600 species divided among 646 genera (Robertson et al., 2008). Within this large and diverse clade, Coccinellidae is remarkable for many of its feeding habits. In the C.S. clade, strict phytophagy is extremely rare and possibly limited to the coccinellid subfamily Epilachninae and the coccinelline genus Bulaea Mulsant, although there is an isolated report of an endomychid, Eumorphus quadriguttatus (Illiger), inflicting damage on betel pepper plants, Piper betel (L.) (Piperaceae) (Mondal et al., 2003).

Even the predominantly predatory habit of Coccinellidae is odd because it constitutes a major exception to the general feeding patterns of the C.S. clade. The other seven C.S. families are primarily mycophagous, with isolated transitions to predation or parasitism being known for only two groups, the genus Saula Gerstaecker (Endomychidae) (Sasaji, 1978; Takagi and Ogata, 1985; Wen, 1995; Takagi, 1999; Leschen, 2000; Chien et al., 2002) and the subfamily Bothriderinae (Bothrideridae) (Crowson, 1981). Saula japonica Gorham preys mainly on scale insects, but is known to feed occasionally on Aleyrodidae (Hemiptera) and Acari (Sasaji, 1978). Bothriderinae are ectoparasites or predators of the immature stages of wood-dwelling Coleoptera and Hymenoptera (Crowson, 1981; Lawrence, 1991).

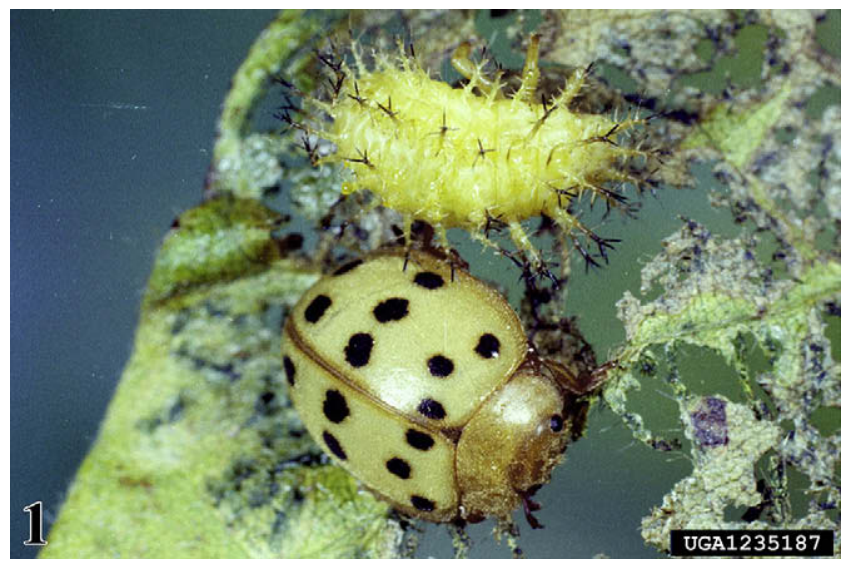

Fig. 1. Epilachna varivestis Mulsant. Adult and larva feeding on soybean Glycine $\max ($ L.). Clemson University, USDA Cooperative Extension Slide Series, www. forestryimages.org.

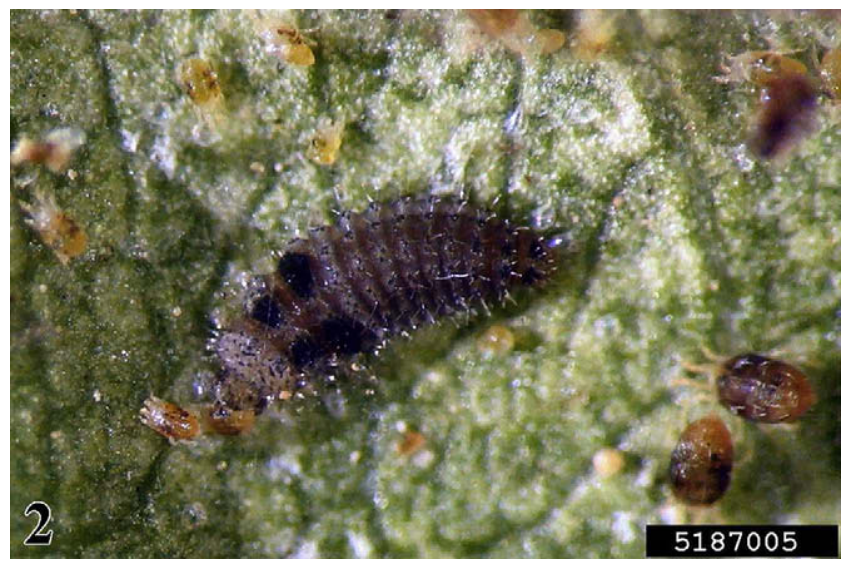

Fig. 2. Stethorus sp. Larva feeding on spider mites. Sonya Broughton, Department of Agriculture \& Food Western Australia, www.bugwood.org.
Given the relevance of coccinellids for biological control, much attention has been given to documenting feeding habits within the family. Although we now have a rudimentary understanding of the food preferences for many species of Coccinellidae, the broad scale evolutionary patterns of these traits remain unclear.

The lack of a phylogenetic framework for the family remains an impediment to understanding the general feeding patterns that have been observed. Since the advent of modern phylogenetic theory and practice, there have been a few attempts to address the higher-level phylogenetic relationships of Coccinellidae (Sasaji, 1971a; Yu, 1994; Kovářr, 1996). Unfortunately, these studies lack a broad taxonomic representation and did not utilize modern phylogenetic methodologies.

The goal of this contribution is to conduct a rigorous phylogenetic analysis of Coccinellidae to provide a framework within which to interpret the evolution of feeding patterns for the family. A general overview of coccinellid classification, phylogeny, and food preferences is provided. Comprehensive treatments of these subjects have been published recently by Hodek and Honěk (1996) (food preferences and classification), Sloggett and Majerus (2000) (food preferences), Ślipiński (2007) (food preferences and classification), and Vandenberg (2002) (classification).

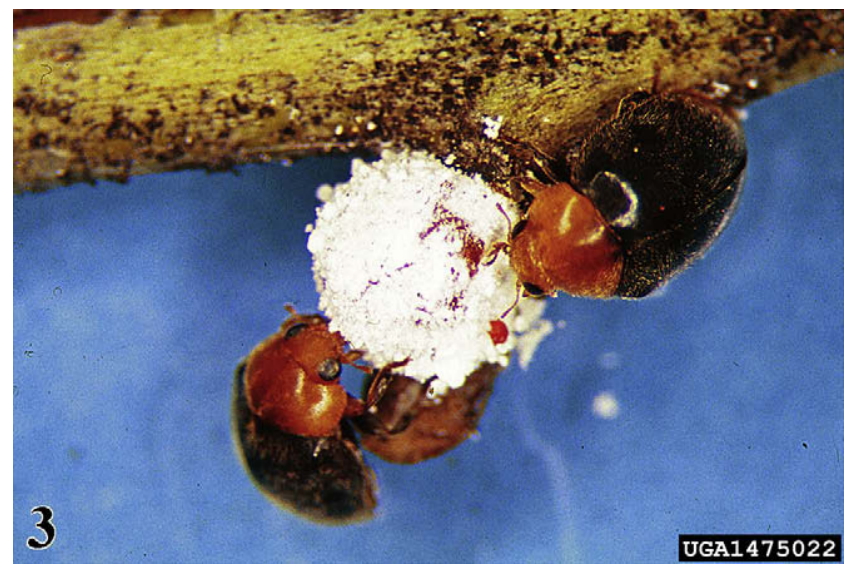

Fig. 3. Cryptolaemus montrouzieri Mulsant. Adults feeding on Hawthorn mealybug Whitney Cranshaw, Colorado State University, www.bugwood.org.

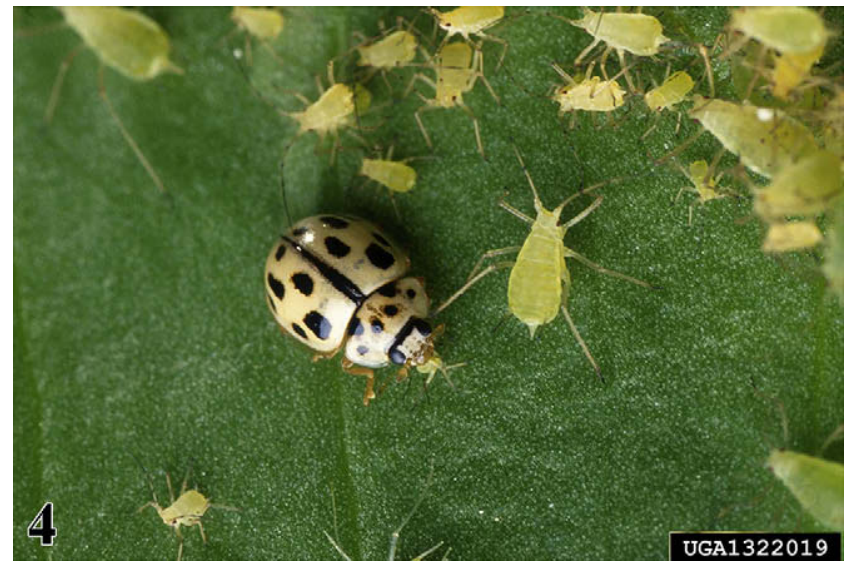

Fig. 4. Propylea quatuordecimpunctata L. Adult feeding on aphids. Scott Bauer, USDA Agricultural Research Service, www.forestryimages.org. 
Table 1

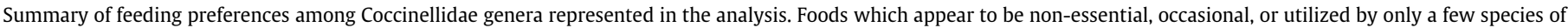
the genus are placed in square brackets.

\begin{tabular}{|c|c|c|}
\hline Taxon & Feeding preferences & Reference \\
\hline \multicolumn{3}{|l|}{ Chilocorinae } \\
\hline Chilocorus Leach 1815 & Coccoidea & Gordon (1985) \\
\hline Exochomus Redtenbacher 1843 & Aphidoidea, Coccoidea & Gordon (1985) \\
\hline Halmus Mulsant 1850 & Coccoidea & Gordon (1985), Ślipiński and Giorgi (2006) \\
\hline Orcus Mulsant 1850 & Coccoidea & Froggatt (1903) \\
\hline Platynaspis Redtenbacher 1844 & Aphidoidea & Kaneko (2007) \\
\hline Telsimia Casey 1899 & Coccoidea & Ślipiński et al. (2005), Ślipiński (2007) \\
\hline \multicolumn{3}{|l|}{ Coccinellinae } \\
\hline Anatis Mulsant 1846 & Aphidoidea [various other insects] & Gordon (1985) \\
\hline Bothrocalvia Crotch 1874 & Unknown & \\
\hline Bulaea Mulsant 1850 & Plants (leaves), Pollen & Savoiskaya (1970, 1983), Capra (1947) \\
\hline Coelophora Mulsant 1850 & Aphidoidea, Coccoidea & Gordon (1985), Chazeau (1981) \\
\hline Coleomegilla Cockerell 1920 & $\begin{array}{l}\text { Aphidoidea, pollen [Chrysomelidae and various } \\
\text { other insects, mites (Tetranychidae), plants } \\
\text { (leaves of corn seedlings)] }\end{array}$ & $\begin{array}{l}\text { Smith (1960), Lundgren et al. (2004, 2005), Gordon (1985), } \\
\text { Groden et al. (1990), Sebolt and Landis (2004), } \\
\text { Moser et al. (2008), Putman (1957) }\end{array}$ \\
\hline Cycloneda Crotch 1871 & Aphidoidea & Gordon (1985) \\
\hline Harmonia Mulsant 1850 & Aphidoidea [various other insects] & Gordon (1985), Sebolt and Landis (2004) \\
\hline Hippodamia Dejean 1837 & Aphidoidea & Hodek and Honěk (1996), Gordon (1985) \\
\hline Illeis Mulsant 1850 & Fungi (Erysiphaceae) & Ślipiński (2007), Anderson (1982) \\
\hline Micraspis Chevrolat 1836 & $\begin{array}{l}\text { Aphidoidea, pollen } \\
\text { [Fulgoroidea, plants (rice panicles)] }\end{array}$ & $\begin{array}{l}\text { Begum et al. (2002), Shepard and Rapusas (1989), } \\
\text { Ślipiński (2007) }\end{array}$ \\
\hline Myzia Mulsant 1846 & Aphidoidea & Gordon (1985), Majerus (1994) \\
\hline Olla Casey 1899 & Psylloidea, Aphidoidea & Gordon (1985) \\
\hline Pristonema Erichson 1847 & Unknown & \\
\hline Psyllobora Dejean 1836 & Fungi (Erysiphaceae) & Gordon (1985) \\
\hline \multicolumn{3}{|l|}{ Coccidulinae } \\
\hline Azya Mulsant 1850 & Coccoidea & Gordon (1985), Almeida and Carvalho (1996) \\
\hline Bucolus Mulsant 1850 & Formicidae (larvae) & Ślipiński (2007) \\
\hline Chnoodes Chevrolat 1837 & Unknown & \\
\hline Coccidula Kugelann 1798 & Aphidoidea & Majerus (1994) \\
\hline Cranophorus Mulsant 1850 & Unknown & \\
\hline Cryptolaemus Mulsant 1853 & Coccoidea & Gordon (1985) \\
\hline Oridia Gorham 1895 & Unknown & \\
\hline Poria Mulsant 1850 & Unknown & \\
\hline Rhyzobius Stephens 1829 & Coccoidea [Aphidoidea] & Gordon (1985) \\
\hline \multicolumn{3}{|l|}{ Epilachninae } \\
\hline Cynegetini Gordon 1975 & Plants & Kuznetsov (1997) \\
\hline Epilachna Costa 1849 & Plants & Gordon (1975) \\
\hline \multicolumn{3}{|l|}{ Ortaliinae } \\
\hline Ortalia Mulsant 1850 & Psylloidea, Formicidae (adult) [Fulgoroidea] & Harris (1921), Samways et al. (1997), Majerus et al. (2007) \\
\hline \multicolumn{3}{|l|}{ Scymninae } \\
\hline Aspidimerus Mulsant 1850 & Aphidoidea & Takahashi (1921) \\
\hline Brachiacantha Dejean 1837 & Aphidoidea, Coccoidea & Gordon (1985) \\
\hline Cryptogonus Mulsant 1850 & Coccoidea & Drea and Gordon (1990) \\
\hline Diomus Mulsant 1850 & Coccoidea [Aphidoidea] & Hall and Bennett (1994), Gordon (1999), Ślipiński (2007) \\
\hline Hyperaspidius Crotch 1873 & Coccoidea & Gordon (1985) \\
\hline Hyperaspis Redtenbacher 1844 & Coccoidea, Aphidoidea & Gordon (1985) \\
\hline Scymnus Kugelann 1794 & Aphidoidea & Lu and Montgomery (2001), Ślipiński (2007) \\
\hline Stethorus Weise 1885 & Acari (Tetranychidae) & Gordon (1985) \\
\hline Tiphysa Mulsant 1850 & Unknown & \\
\hline \multicolumn{3}{|l|}{ Sticholotidinae } \\
\hline Sarapidus Gordon 1977 & Unknown & \\
\hline Serangium Blackburn 1889 & Aleyrodoidea & $\begin{array}{l}\text { Ślipiński and Burckhardt (2006), Gordon (1977), } \\
\text { Hodek and Honěk (1996) }\end{array}$ \\
\hline Sticholotis Crotch 1874 & Coccoidea & Ślipiński (2007), Sasaji (1971) \\
\hline Sulcolotis Miyatake 1994 & Unknown & \\
\hline
\end{tabular}

\subsection{Food preference}

Coccinellids consume many of the same foods as larvae and adults (Majerus, 1994; Hodek, 1996; Vandenberg, 2002). Indirectly, the female even selects the first meals for her offspring by ovipositing in the same area where she has been feeding (Seagraves, 2009). However, not all the foods regularly consumed by adult beetles are nutritionally adequate for reproduction, egg maturation, or larval development. Pollinivory, for example, is common in the so-called "predatory" species but has been found to provide an adequate larval diet for only a few select genera (as discussed below; Lundgren, 2009b).
Three major categories of feeding habits generally are recognized for coccinellids: predation (zoophagy), plant feeding (phytophagy), and fungus feeding (mycophagy) (Figs. 1-5). Most coccinellid species are predaceous on honeydew-producing insects from the hemipteran suborder Sternorrhyncha, although some prefer other arthropod prey. Departing from this predatory habit are the leaf-eaters, which are grouped within Epilachninae and the genus Bulaea, and the fungus feeders, which comprise two small groups from within Coccinellinae, Halyziini and some Tytthaspidini.

Many coccinellid species are known to utilize alternative food items (Figs. 6-9) (Lundgren, 2009b) in the absence of their 


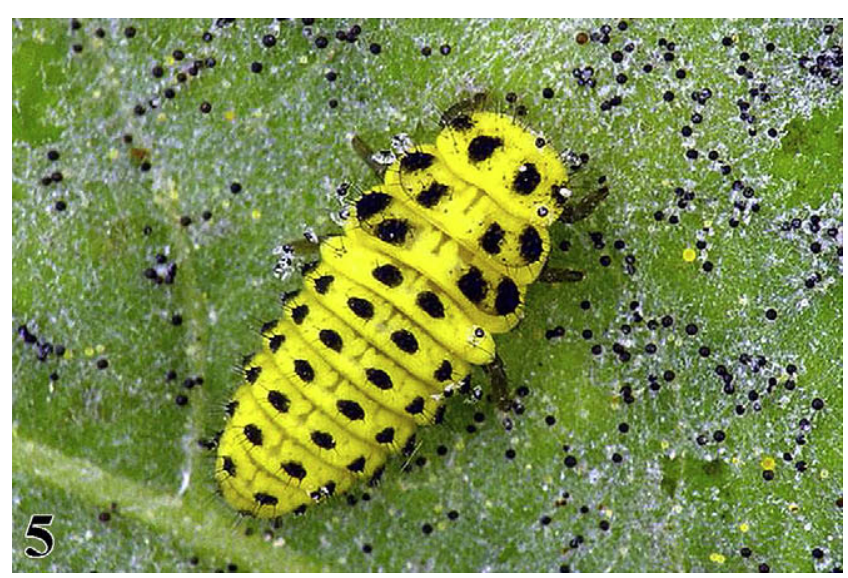

Fig. 5. Psyllobora vigintiduopunctata (L.). Larva on powdery mildew. Stanislav Krejcik, www.meloidae.com.

preferred ones, leading to the distinction between "essential" food sources (i.e., those sufficient for larval development and adult oviposition) (Hodek, 1973, 1996) and merely facultative food sources. The use of honeydew, pollen, sap, nectar, and various fungi as alternative food sources is widespread among the predaceous groups (Pemberton and Vandenberg, 1993; Lundgren, 2009a), as is the exploitation of secondary or less favorable prey species (Hodek, 1973, 1996). In addition, studies by Moser et al. (2008) and Lundgren et al. (2009) suggest that species generally regarded as predaceous may regularly supplement their basic diet with small amounts of leaf material even in the presence of abundant prey and water (zoophytophagy).

Polyphagy also occurs among at least some mycophagous coccinellids which often complement their diet with pollen (Anderson, 1982; Ricci, 1982, 1986; Ricci et al., 1983). The most dietarily restricted coccinellids seem to be the Epilachninae. Thus far, there are no reports of these phytophagous species feeding on anything other than plant tissue.

The hemipteran suborder Sternorrhyncha is divided into four major divisions: Aphidoidea, Psylloidea, Aleyrodoidea, and Coccoidea (Gullan and Martin, 2003; Gullan and Cook, 2007). All three families of Aphidoidea are essential foods for some predaceous coccinellids. Aphids are the preferred prey of most Coccinellini (Ślipiński, 2007), Platynaspidini (Sasaji, 1971a; Ślipiński, 2007), and most Aspidimerini (Poorani, 2001). In the Scymnini, aphids are the primary food source for species of

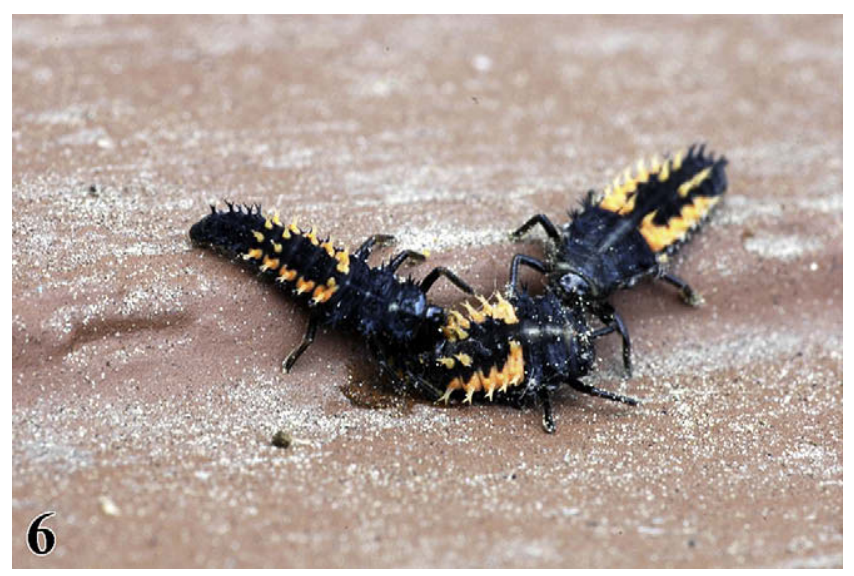

Fig. 6. Harmonia axyridis (Pallas). Larvae cannibalizing a conspecific larva. Armin Hinterwirth, University of Washington.

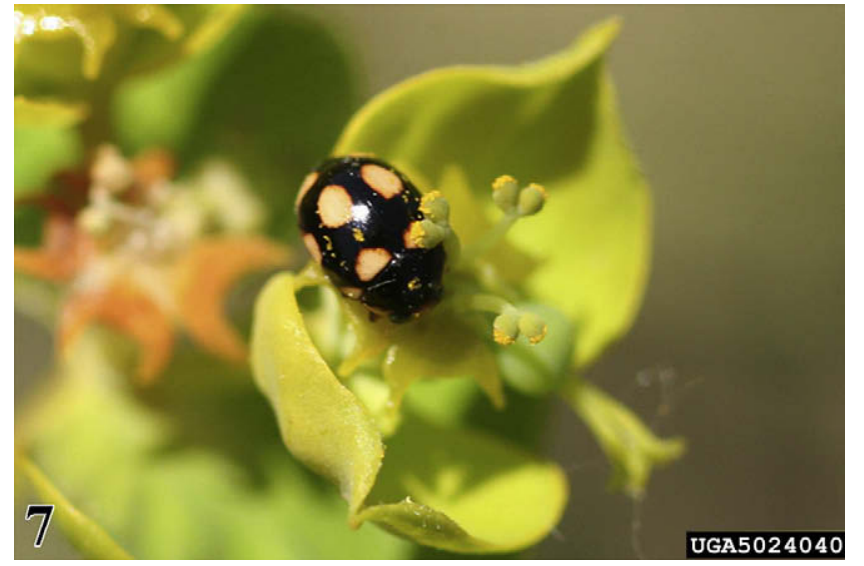

Fig. 7. Hyperaspis sp. Adult feeding on spurge flower pollen. Whitney Cranshaw, Colorado State University, www.bugwood.org.

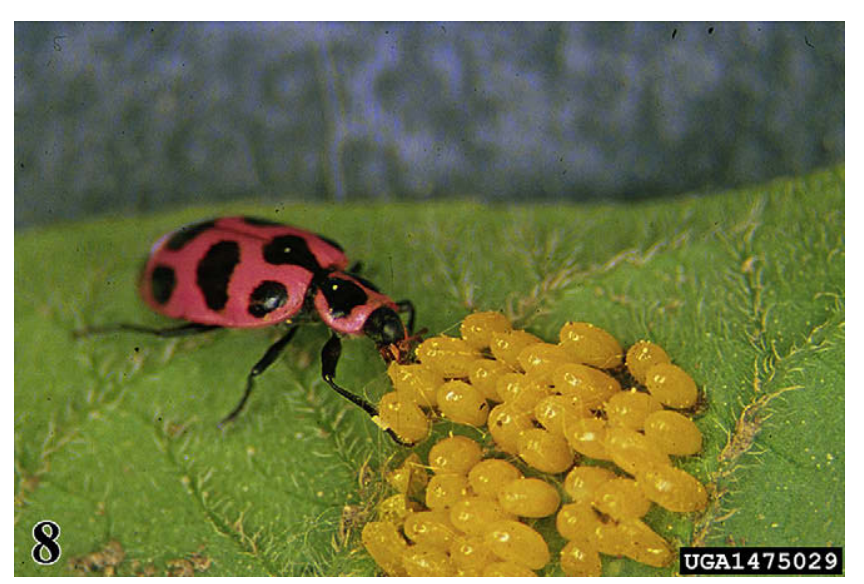

Fig. 8. Coleomegilla strenua (Casey). Adult feeding on eggs of the Colorado potato beetle, Leptinotarsa decemlineata (Say). Whitney Cranshaw, Colorado State University, www.bugwood.org.

Apolinus Pope and Lawrence (Anderson, 1981; as Scymnodes spp.) and most species of the large genus Scymmus Kugelann (Gordon, 1976). At least one instance of essential prey food in the Phylloxeridae has been reported. Wheeler and Jubb (1979) observed Scymnus cervicalis Mulsant preying on grape phylloxera (Daktulosphaira vitifoliae [Fitch]) in Pennsylvania, USA.

Psylloidea are an essential and possibly preferred food item for some Coccinellini (Hodek and Honěk, 2009) such as some species of Calvia Mulsant (Gordon, 1985) and Olla Casey (Michaud, 2001), although these predators also consume and reproduce on aphids. Psyllid-feeding has been reported in the myrmecophilous Ortalia ochracea Weise (Ortaliinae) (Samways et al., 1997).

Aleyrodidae are the preferred food choice for the Serangiini (Sticholotidinae). Two important sticholotidine predators of Bemisia whiteflies are Serangium parcesetosum Sicard (Al-Zyoud and Sengonca, 2004) and Delphastus catalinae (Horn) (Simmons et al., 2008). Within Scymninae, the genera Zilus Mulsant (Scymnillini) and Nephaspis Casey (Scymnini) also feed primarily on whiteflies (Gordon, 1985, 1994). Nephaspis oculatus (Blatchley) is another important predator of Bemisia whiteflies (Liu and Stansly, 1996; Crowder, 2006).

The vast majority of the Scymninae, Chilocorinae, Sticholotidinae and Coccidulinae prey on Coccoidea, and lady beetle predators of scale insects are represented disproportionately among the successful biological control programs that utilize introduced 
Table 2

Comparison of higher-level classification systems of Sasaji (1971a), Kovář (1996) and Ślipiński (2007).

\begin{tabular}{|c|c|c|}
\hline Sasaji (1971a) & Kovář (1996) & $\begin{array}{l}\text { Ślipiński (2007) } \\
\text { (Australian taxa only) }\end{array}$ \\
\hline $\begin{array}{l}\text { Sticholotidinae } \\
\text { Serangiini } \\
\text { Sukunahikonini }\end{array}$ & $\begin{array}{l}\text { Sticholotidinae } \\
\text { Serangiini } \\
\text { Sukunahikonini } \\
\text { Microweiseini } \\
\text { Carinodulini }\end{array}$ & $\begin{array}{l}\text { Microweiseinae } \\
\text { Serangiini } \\
\text { Sukunahikonini } \\
\text { Microweiseini }\end{array}$ \\
\hline $\begin{array}{l}\text { Sticholotidini } \\
\text { Shirozuellini }\end{array}$ & $\begin{array}{l}\text { Sticholotidini } \\
\text { Plotinini } \\
\text { Limnichopharini } \\
\text { Cephaloscymnini } \\
\text { Shirozuellini } \\
\text { Argentipilosini }\end{array}$ & $\begin{array}{l}\text { Coccinellinae } \\
\text { Sticholotidini }\end{array}$ \\
\hline $\begin{array}{l}\text { Coccidulinae } \\
\text { Coccidulini } \\
\text { Exoplectrini } \\
\text { Lithophilini }\end{array}$ & $\begin{array}{l}\text { Coccidulinae } \\
\text { Coccidulini } \\
\text { Exoplectrini } \\
\text { Lithophilini } \\
\text { (as Tetrabrachini) } \\
\text { Azyini } \\
\text { Cranophorini }{ }^{\text {a }} \\
\text { Monocorynini }\end{array}$ & Coccidulini $^{\text {b }}$ \\
\hline Noviini & $\begin{array}{l}\text { Ortaliinae } \\
\text { Noviini }\end{array}$ & Noviini \\
\hline $\begin{array}{l}\text { Scymninae } \\
\text { Cranophorini }\end{array}$ & Ortaliini & \\
\hline $\begin{array}{l}\text { Scymnillini } \\
\text { Scymnini }\end{array}$ & $\begin{array}{l}\text { Scymninae } \\
\text { Scymnillini } \\
\text { Scymnini }\end{array}$ & Scymnillini \\
\hline Aspidimerini & $\begin{array}{l}\text { Aspidimerini } \\
\text { Selvadiini }\end{array}$ & \\
\hline Hyperaspidini & $\begin{array}{l}\text { Hyperaspidini } \\
\text { Brachiacanthini }\end{array}$ & \\
\hline Stethorini & $\begin{array}{l}\text { Stethorini } \\
\text { Cryptognathini } \\
\text { (as Pentiliini) }\end{array}$ & \\
\hline $\begin{array}{l}\text { Chilocorinae } \\
\text { Chilocorini } \\
\text { Platynaspidini } \\
\text { Telsimini }\end{array}$ & $\begin{array}{l}\text { Chilocorinae } \\
\text { Chilocorini } \\
\text { Platynaspidini } \\
\text { Telsimini }\end{array}$ & $\begin{array}{l}\text { Chilocorini } \\
\text { Telsimini }\end{array}$ \\
\hline $\begin{array}{l}\text { Coccinellinae } \\
\text { Coccinellini } \\
\text { Discotomini } \\
\text { Halyziini } \\
\text { (as Psylloborini) }\end{array}$ & $\begin{array}{l}\text { Coccinellinae } \\
\text { Coccinellini } \\
\text { Tytthaspidini } \\
\text { Discotomini } \\
\text { Halyziini } \\
\text { (as Psylloborini) } \\
\text { Singhikalini }\end{array}$ & Coccinellini $^{\mathrm{c}}$ \\
\hline $\begin{array}{r}\text { Epilachninae } \\
\text { Epilachnini }\end{array}$ & $\begin{array}{l}\text { Epilachninae } \\
\text { Epilachnini } \\
\text { Epivertini } \\
\text { Cynegetini } \\
\text { (as Madaiini) } \\
\text { Eremochilini }\end{array}$ & $\begin{array}{l}\text { Epilachninae } \\
\text { Epilachnini }\end{array}$ \\
\hline
\end{tabular}

Coccinellidae (Drea and Gordon, 1990; Gordon, 1985). Although the Diaspididae (armored scales) are by far the most widely exploited prey group (Drea and Gordon, 1990), several other coccoid families are represented by known prey species, including Asterolecaniidae (pit scales), Cerococcidae (ornate pit scales), Coccidae (soft scales), Dactylopiidae (cochineal insects), Eriococcidae (felt scales), Kermesidae (gall-like coccids), Margarodidae (ground pearls), Monophlebidae (giant scales), Ortheziidae (ensign coccids), and Pseudococcidae (mealybugs).
A few coccinellids feed on bugs of the suborders Heteroptera and Auchenorrhyncha. Adults and larvae of Synona melanaria (Mulsant) (Coccinellini) feed on the eggs and nymphs of various species of Coptosoma Laporte (Heteroptera: Plataspidae) (Afroze and Uddin, 1998; Poorani et al., 2008). A relatively large African species of Coccinellini, Anisolemnia tetrasticta Fairmaire, preys on immatures of Plataspidae (Dejean et al., 2002). Some species of Micraspis Chevrolat (Coccinellini) are important predators of brown planthoppers (Auchenorrhyncha: Delphacidae) in rice (Shepard and Rapusas, 1989; Begum et al., 2002). Naemia seriata (Melsheimer) (Coccinellini) feeds on adults and nymphs of Prokelisia planthoppers (Delphacidae) (Finke, 2005). Adults and larvae of Micraspis and Naemia also feed extensively on the pollen produced by the host plants of their delphacid prey.

Among the predaceous Coccinellidae, there are relatively few departures from the widespread reliance on hemipteran prey. The greatest deviation occurs in Stethorini (Scymninae) which prey on spider mites and false spider mites (Acari: Tetranychidae and Tenuipalpidae) (Biddinger et al., 2009), the only non-insects regularly utilized as essential prey by lady beetles (Gordon and Chapin, 1983; Gordon, 1985). Ants represent another unusual prey item that is utilized by relatively few lady beetles (e.g., Bucolus fourneti Mulsant (Coccidulinae) (Ślipiński, 2007), Ortalia ochracea, O. pallens Mulsant (Ortaliini) (Harris, 1921; Samways et al., 1997; Majerus et al., 2007), and Scymnodes bellus Pope and Lawrence (Scymnini) (Pope and Lawrence, 1990)). Majerus et al. (2007) provide an extensive review on the interactions between coccinellids and ants. Six species of Coccinellini (Coccinellinae) have been recorded as specialized predators of the immature stages of Chrysomelidae (Coleoptera): Aiolocaria hexaspilota (=mirabilis) Hope (Iwata, 1932, 1965; Savoiskaya, 1970), Calvia quindecimguttata L. (Kanervo, 1940), Coccinella hieroglyphica L. (Hippa et al., 1977, 1978, 1982, 1984), Oenopia conglobata (L.) (Kanervo, 1940, 1946), Propylea quatuordecimpunctata L. (Iablokoff-Khnzorian, 1982), and Neoharmonia venusta (Melsheimer) (Whitehead and Duffield, 1982). In addition to the non-hemipteran hosts mentioned above, the larvae of Diptera, Lepidoptera, and Thysanoptera are also utilized as prey by some coccinellids (Hodek, 1973, 1996; Evans, 2009).

Some coccinellids have adopted an arthropod-free diet, relying instead on fungal or plant material for their primary source of nourishment. The conidia and hyphae of powdery mildews (Ascomycota: Erysiphales) appear to be the main food source for all members of Halyziini (e.g., Psyllobora Mulsant, Halyzia Mulsant, Thea Mulsant, Illeis Mulsant (=Leptothea Weise), and Vidibia Mulsant) (Turian, 1969; Hodek, 1973; Gordon, 1985; Vandenberg, 2002; Ślipiński, 2007; Sutherland and Parrella, 2009). Another tribe of Coccinellinae, Tytthaspidini, also includes species that favor mycophagy (e.g., Tytthaspis sedecimpunctata (L.) (Turian, 1969)); however, these species have not completely abandoned predation (Ricci, 1982).

All members of the subfamily Epilachninae are leaf-eating herbivores. Epilachnini feed on Aristolochiaceae, Curcubitaceae, Solanaceae (Gordon, 1975), Berberidaceae, Asteraceae (Hirai et al., 2006), Poaceae (Beyene et al., 2007; Igbinosa et al., 2007), and Fabaceae (Vandenberg, 2002). The Cynegetini have been reported to eat only Fabaceae (Kuznetsov, 1997). Outside Epilachninae, leaf-eating has been reported for Bulaea lichatschovi (Hummel) (Coccinellinae: Tytthaspidini) (Savoiskaya, 1970). Coleomegilla Cockerell, Micraspis, and Harmonia Mulsant have been reported to feed on plant tissue. Moser et al. (2008) demonstrated that Coleomegilla and Harmonia larvae regularly ingest small amounts of plant tissue from the leaves and coleoptiles of corn seedlings even in the presence of abundant prey, and Pathak and Khan (1994) found that, while Micraspis spp. generally play a beneficial role in controlling rice plant pests, both adults and larvae will damage leaf blades, hulls, and even developing rice grains in the absence of prey. 

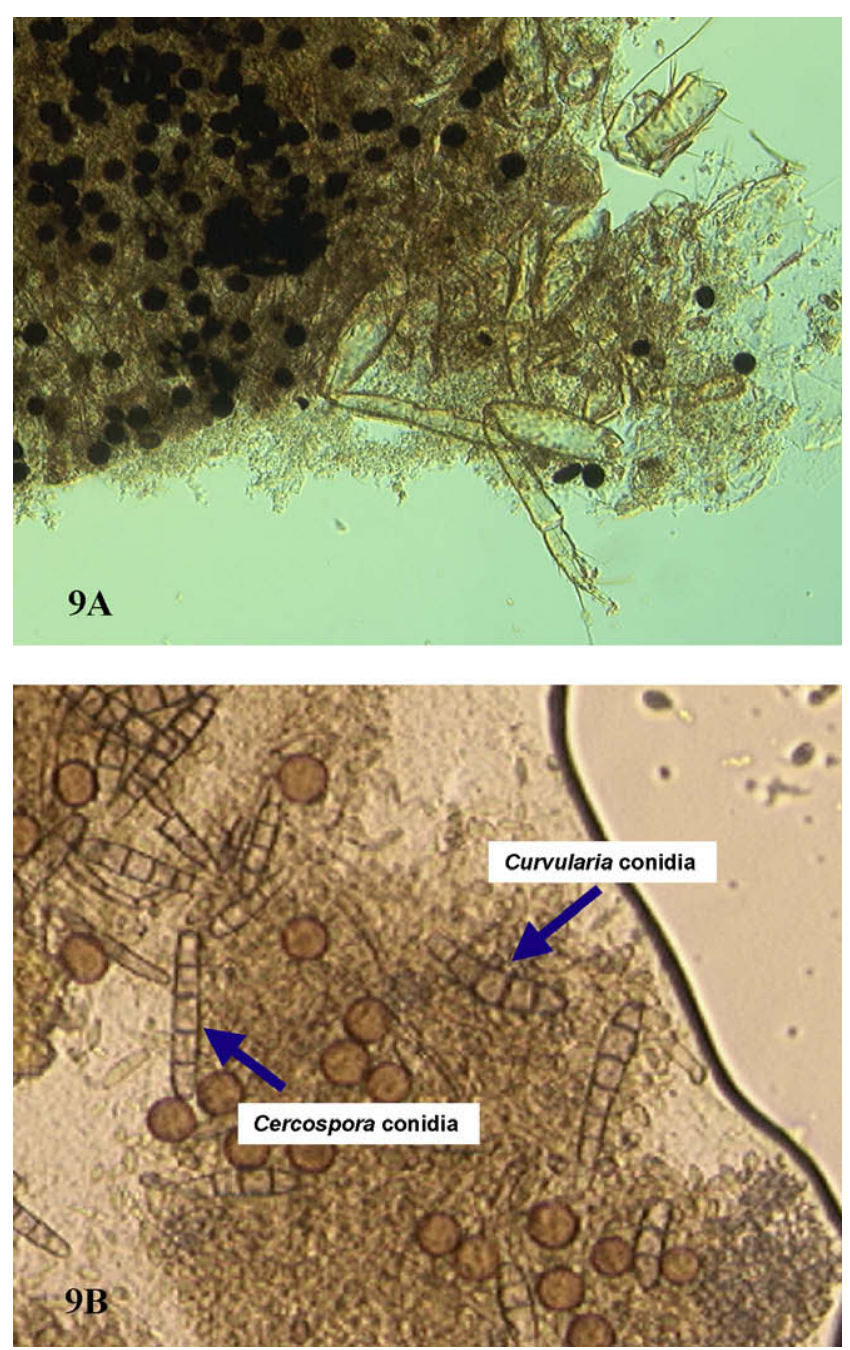

Fig. 9. Gut contents of "carnivorous" Exoplectrini spp. Adriano Giorgi, University of Georgia. (A) Gut contents including sternorrhyncan prey remains and fungal spores. (B) Gut contents including conidia of Curvularia sp. and Cercospora sp.

Pollen, honeydew, and nectar constitute a significant, if not essential, food item for most coccinellids (Hodek, 1973; Pemberton and Vandenberg, 1993; Lundgren, 2009a,b). Pollen is a major component in the diet of $T$. sedecimpunctata (L.) (Ricci et al., 1983; Ricci, 1986) and has also been reported to be an essential food for B. lichatschovi, and some congeners (Capra, 1947; Savoiskaya, 1983). Among the carnivores, species of Coleomegilla and Micraspis feed extensively on pollen (Britton, 1914; Putman, 1964; Benton and Crump, 1981; Turner and Hawkeswood, 2003; Omkar, 2006;

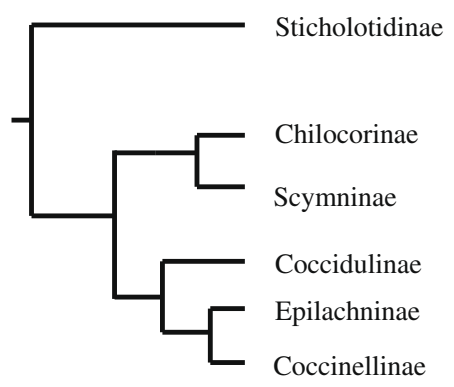

Fig. 10. Schematic phylogenetic tree interpreted from the dendrogram and accompanying text of Sasaji $(1968,1971 a, b)$ showing only relationships among lady beetle subfamilies.

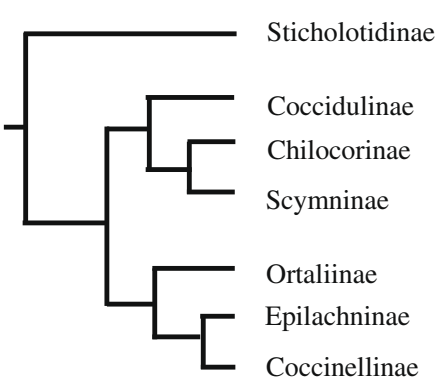

Fig. 11. Schematic phylogenetic tree interpreted from Kovář (1996) showing only relationships among lady beetle subfamilies.

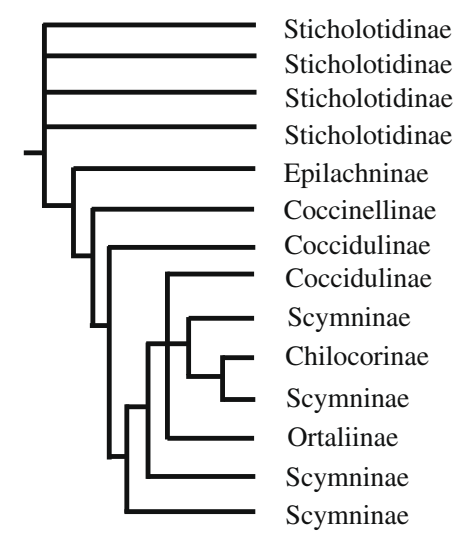

Fig. 12. Schematic phylogenetic tree from cladogram published by Yu (1994) showing only relationships among lady beetle subfamilies.

Lundgren et al., 2004, 2005; Lundgren, 2009a) and are among the few primarily predaceous species documented as capable of completing their life cycle on a pollen-only diet (Smith, 1960; Shepard and Rapusas, 1989; Lundgren and Wiedenmann, 2004).

\subsection{Classification}

Redtenbacher (1844) proposed the first subfamilial classification system for Coccinellidae by recognizing two biologically defined groups, the plant feeders and the aphid feeders. The phytophagous group corresponds to the current subfamily Epilachninae but the aphidophagous group spans the other currently recognized subfamilies. Mulsant $(1846,1850)$ also divided the family into two groups: the hairy species ("Trichoisomides") and the glabrous ones ("Gymnosomides"), but this system was even more artificial than its predecessor. Mulsant $(1846,1850)$, however, made an important contribution to coccinellid classification by recognizing supra-generic categories that correspond to the current tribes in Coccinellidae. In Korschefsky's (1931) classification three subfamilies are recognized: Epilachninae, Coccinellinae, and Lithophilinae. This system is consistent with that of Redtenbacher but it further subdivided the carnivores ("aphidophagous") on the basis of the tarsal structure. Despite these advances, the classification of Coccinellidae was still rudimentary and extremely artificial until the second half of the 20th century.

Sasaji (1968, 1971a,b) proposed a revised classification based on a careful investigation of larval and adult morphology. His system of six subfamilies (Sticholotidinae, Coccidulinae, Scymninae, Chilocorinae, Coccinellinae, and Epilachninae) was widely accepted and remains the primary reference for the family (e.g., Booth et al., 1990; Pakaluk et al., 1994; Lawrence and Newton, 1995; Kuznetsov, 1997). 
Additional subfamilies have since been recognized: Azyiinae and Exoplectrinae, elevated from tribal status (Gordon, 1994); Ortaliinae, for Ortaliini plus Noviini (Kovář, 1996); and Hyperaspidinae, for Hyperaspidini plus Brachiacanthini (Duverger 1989, 2001). In a work published posthumously, Duverger (2003), attached a distinct subfamily name to each of the 18 major groupings in Kovářrs dendrogram (1996), but unfortunately, a number of these names were invalid (based on junior synonyms), misspelled, or applied inconsistently within the different sections of the same paper. Ślipiński (2007) attempted to reverse current trends by suggesting a system based on only two subfamilies: Microweiseinae (=Scotoscymninae Duverger) for the "primitive" members of Sticholotidinae, and a very broadly defined Coccinellinae for the remaining taxa. None of these various classifications has received a universal following (see Table 2 for a comparison of some of these contemporary classification systems).

Many regional taxonomic monographs have been published in the last three decades, including: Fürsch (1967) [European fauna]; Gordon (1985) [North America]; Hoang (1982, 1983) [Vietnam]; Iablokoff-Khnzorian (1982) [Palearctic and Oriental regions]; Kuznetsov (1997) [Russian Far East]; Pang and Mao (1979) [China]; Pope (1989) [Australian Coccinellinae]; Sasaji (1971a) [Japan]; and Savoiskaya (1983) [Central Asia and parts of the former USSR].

Because these treatments were geographically limited, many of the new genera and tribes proposed in them have ranges that are restricted to the geographical scope of the studies, even though the subfamilies are distributed worldwide (Vandenberg, 2002). This has resulted in many alternative classifications (see Table 2), none of which are easily reconciled (Vandenberg, 2002).

\subsection{Phylogeny}

Although the monophyly of the C.S. is well supported by molecular data (Hunt et al., 2007; Robertson et al., 2008), the closest relative of Coccinellidae remains unclear. Morphological considerations supported hypotheses that the sister group was a clade comprising Endomychidae plus Corylophidae (Sasaji, 1971a; Crowson, 1981) or one comprising Endomychidae plus Alexiidae (Ślipiński and Pakaluk, 1991). These hypotheses were strictly intuitive, not based on formal phylogenetic analyses.

There have been formal phylogenetic studies of other C.S. taxa which provide insights about the closest relatives of Coccinellidae. Each of these studies, however, addressed different phylogenetic questions, so taxonomic sampling differed. In these studies, the following taxa were recovered as close relatives of Coccinellidae: Endomychidae (Tomaszewska, 2000), Anamorphinae (Endomychidae) plus Alexiidae (Hunt et al., 2007), and Corylophidae (Tomaszewska, 2005). In a parsimony analysis Robertson et al. (2008) found Leiestinae (Endomychidae) to be the sister taxon to Coccinellidae; however, a Bayesian analysis of the same data was ambiguous, suggesting that the sister group was either Endomychidae minus Anamorphinae, or Corylophidae plus Anamorphinae.

There have been a few attempts to address the higher-level phylogenetic relationships of Coccinellidae. Sasaji (1968, 1971a,b) and Kovář (1996) provided intuitive hypotheses (Figs. 10 and 11), not generated by formal phylogenetic methods. The relationships proposed by Sasaji $(1968,1971 \mathrm{a}, \mathrm{b})$ have received widespread acceptance. Under this hypothesis (Fig. 10), the subfamily Sticholotidinae is considered the most "primitive" group in the family, diverging from the rest of the coccinellids at the most basal split. On the main branch, two other major lineages were proposed: one including the subfamilies Scymninae and Chilocorinae, and the other including Coccidulinae, Coccinellinae, and Epilachninae. In the latter group, Coccidulinae was considered the sister group to the Coccinellinae plus Epilachninae branch.
Kovář (1996) modified Sasaji's hypothesis by moving Coccidulinae to the base of the Scymninae plus Chilocorinae branch (Fig. 11) and by recognizing a new subfamily, Ortaliinae, which represented Noviini (previously in Coccidulinae) and Ortaliini (previously in Scymninae). Kovář considered the Ortaliinae to be the sister taxon to the Coccinellinae plus Epilachninae branch.

Yu (1994) conducted cladistic analyses using adult and larval morphological characters to address higher-level relationships; however, the two data partitions (adult and larval characters) were analyzed separately and produced drastically conflicting topologies. The adult-based topology (Fig. 12) maintained Sticholotidinae at the base, but did not recover the subfamily as monophyletic. Epilachninae diverged from the rest of the family at the next highest node, followed by the Coccinellinae. In the sister group to the latter, Coccidulinae was recovered as paraphyletic with respect to Ortaliinae, Chilocorinae, and Scymninae. Chilocorinae and Ortaliinae were nested within Scymninae, rendering it paraphyletic. Epilachninae was recovered as basal in the larval analysis, and was the only monophyletic subfamily recovered. A close relationship between Serangiini and Sukunahikonini was the only point of similarity between the adult and larval topologies.

\section{Materials and methods}

\subsection{Taxon sampling}

For the purpose of this study, the tribal and subfamilial classification scheme of Kovár (1996) was followed because it represents the most recent, global treatment of the family. Tribal names have been updated to reflect current synonymies (Table 2) and two additional tribes, Poriini and Diomini (Gordon, 1994, 1999), have been added to the classification. Taxonomic exemplars for this analysis (Table 3 ) were obtained for 24 of 38 coccinellid tribes: Chilocorini, Platynaspidini, and Telsimini (Chilocorinae); Coccinellini, Discotomini, Halyziini, and Tytthaspidini (Coccinellinae); Azyini, Coccidulini, Cranophorini, Exoplectrini, and Poriini (Coccidulinae); Epilachnini and Cynegetini (Epilachninae); Ortaliini (Ortaliinae); Aspidimerini, Brachiacanthini, Diomini, Hyperaspidini, Scymnini, and Stethorini (Scymninae); and Microweiseini, Serangiini, and Sticholotidini (Sticholotidinae). This taxon sampling represents all 11 formally proposed subfamilies, excluding those elevated only by Duverger (2003). The outgroup taxa comprise five representatives from three C.S. families: Discolomatidae (1), Endomychidae (3), and Latridiidae (1). One representative of the family Erotylidae, a non-C.S. cucujoid, also was included in the analysis as a distant outgroup. Thus, a total of 62 (56 ingroups and 6 outgroups) taxa were represented in this study.

\subsection{Nuclear sampling and laboratory procedures}

Genomic DNA was extracted using the Qiagen DNeasy tissue kit (Valencia, CA). Target genes 18S rDNA and 28S rDNA were amplified via polymerase chain reaction (PCR). PCR primers and protocols are published elsewhere (Jarvis et al., 2004; Whiting, 2002). Primer combinations utilized for $18 \mathrm{~S}$ include $1 \mathrm{~F}+\mathrm{B} 3.9, \mathrm{a} 0.7+\mathrm{bi}$, and a2.0 + 9R (Whiting, 2002; Jarvis et al., 2004). Primer combinations used for $28 \mathrm{~S}$ include $1 \mathrm{a}+28 \mathrm{Sb}, 28 \mathrm{Sa}+5 \mathrm{~b}$, and $4.8 \mathrm{a}+7 \mathrm{~b} 1$ (Whiting, 2002). PCR product yield, specificity, and potential contamination were monitored by agarose gel electrophoresis. PCR products were purified using MANU96-well filtration plates, sequenced using D-rhodamine chemistry, and fractionated on an ABI3730 DNA analyzer at the Brigham Young University (BYU) DNA Sequencing Center. Assembly of contig sequences and editing of nucleotide fragments were performed using Sequencher 3.1.1 (Genecodes, 1999). Alignment of these data was performed in MAFFT (Edgar, 
Table 3

List of taxa used in the analysis including GenBank accession numbers. Dash represents missing data.

\begin{tabular}{|c|c|c|c|c|c|}
\hline Family & Subfamily & Tribe & Species & $18 \mathrm{~S}$ & $28 \mathrm{~S}$ \\
\hline Erotylidae & Tritominae & & Pselaphacus nigropunctatus & EU164627 & EU164657 \\
\hline Discolomatidae & Aphanocephalinae & & Aphanocephalus sp. & EU145628 & EU145687 \\
\hline \multirow[t]{3}{*}{ Endomychidae } & Lycoperdininae & & Corynomalus laevigatus & EU164639 & EU164646 \\
\hline & & & Lycoperdina ferruginea & EU145637 & EU145695 \\
\hline & & & Mycetina horni & EU145641 & EU145699 \\
\hline Latridiidae & Latridiinae & & Latridius crenatus & EU164623 & EU164654 \\
\hline \multirow[t]{56}{*}{ Coccinellidae } & Chilocorinae & Chilocorini & Chilocorus cacti & EU145610 & - \\
\hline & & & Exochomus quadripustulatus & FJ687695 & FJ687736 \\
\hline & & & Halmus coelestris & FJ687687 & FJ687728 \\
\hline & & & Halmus chalybeus & EU145607 & EU145669 \\
\hline & & & Orcus lafertei & FJ687689 & FJ687730 \\
\hline & & & Orcus bilunulatus & FJ687699 & FJ687740 \\
\hline & & Platynaspidini & Platynaspis sp. & EU145619 & EU145678 \\
\hline & & Telsimini & Telsimia sp. & FJ687697 & FJ687738 \\
\hline & Coccidulinae & Azyini & Azya orbigera & FJ687666 & FJ687707 \\
\hline & & Coccidulini & Coccidula sp. & FJ687702 & FJ687743 \\
\hline & & & Rhyzobius sp. & FJ687700 & FJ687741 \\
\hline & & & Rhyzobius lophanthae & FJ687674 & FJ687716 \\
\hline & & Cranophorini & Cranophorus sp. & FJ687669 & FJ687710 \\
\hline & & Exoplectrini & Chnoodes sp. & EU145606 & EU145668 \\
\hline & & & Oridia pubescens & FJ687693 & FJ687734 \\
\hline & & Poriini & Poria sp. & FJ687692 & FJ687733 \\
\hline & & Insertae Sedis & Bucolus fourneti & FJ687704 & FJ687745 \\
\hline & & & Cryptolaemus montrouzieri & FJ687668 & FJ687709 \\
\hline & Coccinellinae & Coccinellini & Anatis labiculata & - & FJ687714 \\
\hline & & & Bothrocalvia albolineata & FJ687688 & FJ687729 \\
\hline & & & Coelophora bisellata & FJ687679 & FJ687721 \\
\hline & & & Coleomegilla strenua & FJ687672 & FJ687713 \\
\hline & & & Cycloneda sanguinea & FJ687681 & FJ687723 \\
\hline & & & Harmonia axyridis & FJ687676 & FJ687718 \\
\hline & & & Harmonia eucharis & EU145612 & EU145672 \\
\hline & & & Hippodamia quinquesignata & FJ687673 & FJ687715 \\
\hline & & & Hippodamia apicalis & FJ687683 & - \\
\hline & & & Micraspis sp. & FJ687678 & FJ687720 \\
\hline & & & Myzia pullata & FJ687671 & FJ687712 \\
\hline & & & Olla v-nigrum & FJ687675 & FJ687717 \\
\hline & & Discotomini & Pristonema sp. & FJ687665 & FJ687706 \\
\hline & & Halyziini & Illeis sp. & FJ687680 & FJ687722 \\
\hline & & & Psyllobora vigintimaculata & EU145604 & EU145666 \\
\hline & & & Psyllobora sp. & FJ687691 & FJ687732 \\
\hline & & Tytthaspidini & Bulaea anceps & FJ687667 & FJ687708 \\
\hline & Epilachninae & Cynegetini & Cynegetini sp. & EU145608 & - \\
\hline & & Epilachnini & Epilachna sp. & EU145616 & EU145675 \\
\hline & Ortaliinae & Ortaliini & Ortalia sp. & EU145617 & EU145676 \\
\hline & & & Ortalia horni & EU145614 & - \\
\hline & Scymninae & Aspidimerini & Aspidimerus sp. & FJ687696 & FJ687737 \\
\hline & & & Cryptogonus sp. & FJ687698 & FJ687739 \\
\hline & & Brachiacanthini & Brachiacantha sp. & FJ687694 & FJ687735 \\
\hline & & & Tiphysa sp. & EU145620 & EU145679 \\
\hline & & Diomini & Diomus kamerungensis & FJ687701 & FJ687742 \\
\hline & & & Diomus notescens & FJ687703 & FJ687744 \\
\hline & & Hyperaspidini & Hyperaspidius mimus & FJ687684 & FJ687725 \\
\hline & & & Hyperaspis lateralis & FJ687685 & FJ687726 \\
\hline & & & Hyperaspis sp. & EU145611 & EU145671/EU145714 \\
\hline & & Scymnini & Scymnus sp. 1 & EU145603 & EU145665 \\
\hline & & & Scymmus sp. 2 & FJ687682 & FJ687724 \\
\hline & & Stethorini & Stethorus sp. & EU145617 & EU145676 \\
\hline & Sticholotidinae & Serangiini & Serangium sp. & FJ687690 & FJ687731 \\
\hline & & Microweiseini & Serapidus sp. & FJ687670 & FJ687711 \\
\hline & & Sticholotidini & Sticholotis sp. 1 & FJ687677 & FJ687719 \\
\hline & & & Sticholotis sp. 2 & FJ687686 & FJ687727 \\
\hline & & & Sulcolotis sp. & FJ687705 & FJ687746 \\
\hline
\end{tabular}

2004) using default parameters. Voucher specimens were deposited in the University of Georgia Coleoptera Tissue Collection and genomic DNA in the BYU Insect Genomics Collection. All novel sequences were submitted to GenBank (see Table 3 for accession numbers).

\subsection{Phylogenetic analysis}

Phylogenetic reconstruction of the concatenated $18 \mathrm{~S}$ and $28 \mathrm{~S}$ data was conducted under the parsimony criterion using TNT (version 1.1, Goloboff et al., 2003). Heuristic searches were performed under the "new technology search" (with sectorial searches, tree drifting, tree fusing, and ratcheting) implementing 5000 replicates, holding 10 per replicate to a maximum of 10,000 trees. Multistate characters were treated as non-additive, gaps were treated as missing data, and all characters were weighted equally. All trees were rooted to Pselaphacus nigropunctatus (Coleoptera: Erolytidae). TNT was used to estimate branch support with non-parametric bootstrap values (Felsenstein, 1985) and Bremer support values (Bremer, 1994). To calculate bootstrap values we 
performed 1000 replicates with 10 random sequence additions per replicate.

Bayesian analysis of the $18 \mathrm{~S}$ and $28 \mathrm{~S}$ data was performed in MrBayes (version 3.1.2, Ronquist and Huelsenbeck, 2003). Modeltest (Posada and Crandall, 1998) was used to select an appropriate model of sequence evolution for each gene under the AIC (Akaike Information Criterion) and these models were implemented in the Bayesian analysis. The partitioned Bayesian analysis comprised four separate runs each utilizing five million generations, flat priors, unlinked partitions, four chains (one cold and three hot), and trees sampled every 1000 generations. Log-likelihood scores were plotted to determine stationarity and convergence of runs. Trees sampled after the "burn-in" from the four runs were combined and used to construct a 50\% majority-rule consensus tree. Branch support was assessed with posterior probabilities determined via the $50 \%$ majority-rule consensus percentages.

\subsection{Character scoring/mapping of food preferences}

We scored prey/host association data for each terminal taxon included in the analysis based on records extracted from the literature. To score terminals identified only to genus or tribe, we combined all known food data for all member species. Sternorrhynchan prey were coded to the superfamilial level following the classification of Carver et al. (1991). Four superfamilies were represented: Aphidoidea, Psylloidea, Aleyrodoidea, and Coccoidea. Whenever evidence was provided, we constrained prey associations to essential food items only. Otherwise, we coded food preference based on all convincing records available. To enable character optimization and permit interpretation of the evolutionary sequence of feeding shifts, we constructed polymorphic character states for taxa that utilized more than a single category of food. Food preferences were then mapped on the Bayesian majority-rule consensus tree by simple, unambiguous character optimization with MacClade (version 4.06, Maddison and Maddison, 2003).

\section{Results}

\subsection{Sequences and alignment}

Sequences for the $18 \mathrm{~S}$ ranged from 1826 to $1845 \mathrm{bp}$. For 28S, the sequences were larger and ranged from 2116 to $2209 \mathrm{bp}$. Some highly variable regions of $28 \mathrm{~S}$ were removed and excluded from further analysis based on the premise that they were too variable in length to be reasonably aligned. These regions occurred at the nucleotide positions 401-493, 949-976, 1612-1648, and 1859-2029.

\subsection{Phylogenetic analysis}

Alignment of the molecular data yielded a matrix of 3957 characters, 1881 for $18 \mathrm{~S}$ and 2076 for 28S. This combined matrix comprised 787 parsimony informative characters, 292 for $18 \mathrm{~S}$ and 495 for 28S. The parsimony analyses resulted in six most parsimonious trees (4069 steps, $C I=41, R I=63$ ). The strict consensus tree is shown in Fig. 13.

The hierarchical AIC as implemented in Modeltest yielded the General Time Reversible + Invariable Site + Gamma Distribution $(\mathrm{GTR}+\mathrm{I}+\mathrm{G})$ model of sequence evolution as most appropriate for both the $18 \mathrm{~S}$ and $28 \mathrm{~S}$ partitions. All Bayesian runs reached stationarity by 100,000 generations. The sampled trees from these first 500,000 generations (500 trees per run, 2000 trees total) were discarded as "burn-in" and the remaining 18,000 sampled trees from the four runs were combined and used to construct the $50 \%$ majority-rule consensus tree (Fig. 14). Nodes in the cladograms are numbered for reference in the discussion below.

\section{Discussion}

\subsection{Phylogenetic relationships of Coccinellidae}

This study represents one of the few formal phylogenetic analyses for the higher-level taxa of Coccinellidae and is the first to utilize molecular data to address 2009. The resulting topologies from the parsimony and Bayesian analyses agree in many critical aspects (see Fig. 13 for points of agreement).

The analyses support the monophyly of Coccinellidae [Node 1, bootstrap $(B S)=82$, Bremer $(B R)=13$, Posterior Probability $(P P)=1.00$ ] (Figs. 13 and 14). Although taxon sampling was broad, future analyses could improve on it by including representatives of Alexiidae and the endomychid subfamilies Anamorphinae and Leiestinae, since each of these taxa has recently been proposed as a close relative of Coccinellidae. The addition of exemplars for Mycetaeinae and Eupsilobiinae (both Endomychidae) would also strengthen this test because these taxa have conspicuous morphological similarities with some coccinellids (Pakaluk and Ślipiński, 1990; Ślipiński, 2007), but they have not yet been included in a phylogenetic study of the family.

The earliest divergence places the tribes Serangiini and Microweiseini as a well-supported, monophyletic sister group [Node 2, $\mathrm{BS}=100, \mathrm{BR}=53, \mathrm{PP}=1.00$ ] of a large clade representing the remainder of the coccinellids [Node $3, \mathrm{BS}=75, \mathrm{BR}=10, \mathrm{PP}=1.00$ ]. The placement of the Serangiini plus Microweiseini clade as the sister group to the remaining coccinellids is consistent with the hypotheses of Sasaji (1968, 1971a,b), Yu (1994), and Kovár (1996) (Figs. 10-12).

These analyses do not support the monophyly of Sticholotidinae as currently defined (Figs. 13-15). Vandenberg and Perez-Gelabert (2007) questioned the monophyly of Sticholotidinae since it appeared to include two distinctive lineages that differed significantly in the form of the apical maxillary palpomere. Vandenberg and Perez-Gelabert (2007) regarded the small sensory surface of the palp of Serangiini to be primitive and that of Sticholotidini to be more advanced, an observation supported by the findings of this phylogenetic study. Ślipiński (2007) provided other morphological arguments against the Sticholotidinae (sensu Sasaji) and erected the subfamily Microweiseinae to accommodate Serangiini, Microweiseini, and Sukunahikonini. The establishment of Microweiseinae receives additional justification from the findings of this phylogenetic study.

One node higher on the phylogenetic tree, a second major division takes place, splitting the well-supported subfamily Coccinellinae [Node $4, \mathrm{BS}=100, \mathrm{BR}=36, \mathrm{PP}=1.00$ ] from the remaining coccinellids (Figs. 13-15). This finding contradicts the classical sister group relationship between Coccinellinae and Epilachninae as hypothesized by Sasaji (1968) and Kovář (1996). It also contradicts the hypothesis of Yu (1994), which placed Epilachninae as the sister group of the remaining coccinellids at the second major division.

Coccinellinae is recovered as monophyletic (Node 4, Figs. 1315). Within Coccinellinae, the tribe Discotomini (here represented by Pristonema sp.) is recovered as the sister group of the remaining Coccinellinae. Members of Discotomini have very distinct serrate antennae but overall, share most of the characteristics of Coccinellinae (glabrous body, long and dorsally inserted antennae, and strongly securiform maxillary palpi).

The tribes Halyziini (here represented by the genera Illeis and Psyllobora, Node 6) and Tytthaspidini (here represented by Bulaea anceps) are nested within a well-supported clade [Node 5, $\mathrm{BS}=95, \mathrm{BR}=10, \mathrm{PP}=0.99$ ], rendering Coccinellini paraphyletic. Given their specialized host preferences and distinct mandibular anatomy, these two groups have been given tribal level recognition 


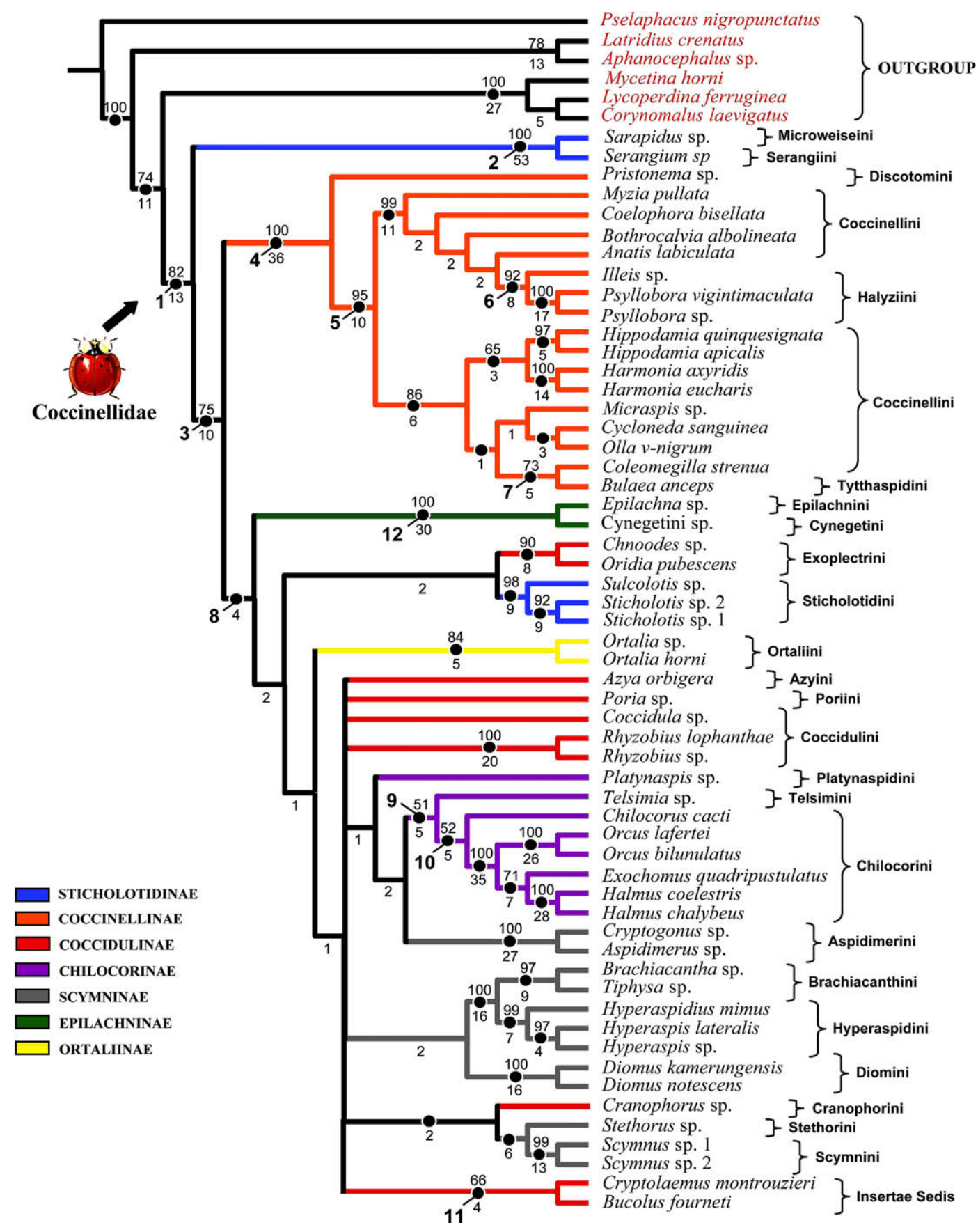

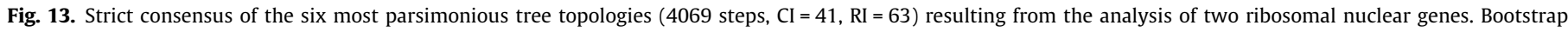

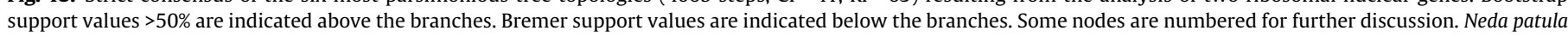
image: courtesy of Guillermo González, www.coccinellidae.cl.

(Hodek, 1973). The mandibles in Halyziini and Tytthaspidini have adaptations for scraping associated with their fungivorous and pollinivorous diets (Samways et al., 1997). Our study suggests that these tribes are derived lineages that arose within the two main branches of the generally aphidophagous tribe Coccinellini. In fact, despite differences in the shape of the mandible, both tribes have the distinct bifid incisive tooth characteristic of Coccinellini (Samways et al., 1997), providing further evidence for their placement within this clade.

A clade that includes Epilachninae, Coccidulinae, Ortaliinae, Scymninae, Chilocorinae, and the remaining Sticholotidinae (i.e., Sticholotidini) is supported by both the parsimony and Bayesian analyses [Node $8, \mathrm{BR}=4, \mathrm{PP}=0.56$ ]. The support for this node is low; many of the relationships within it are poorly supported and show conflict between the two hypotheses, particularly at the deeper nodes. Nevertheless, there is some agreement between both topologies. The subfamilies Scymninae, Chilocorinae, and Coccidulinae are recovered as paraphyletic as presently defined. These results are not surprising given the lack of strong morphological or behavioral evidence to support these groups.

Despite the paraphyletic status of Chilocorinae, our study supported the sister group relationship between the tribes Telsimini and Chilocorini [Node 9, BS $=51, \mathrm{BR}=5, \mathrm{PP}=0.98$ ]. The unifying characteristic of this subfamily, the lateral expansion of the clypeus, is suspected to have evolved independently many times in 


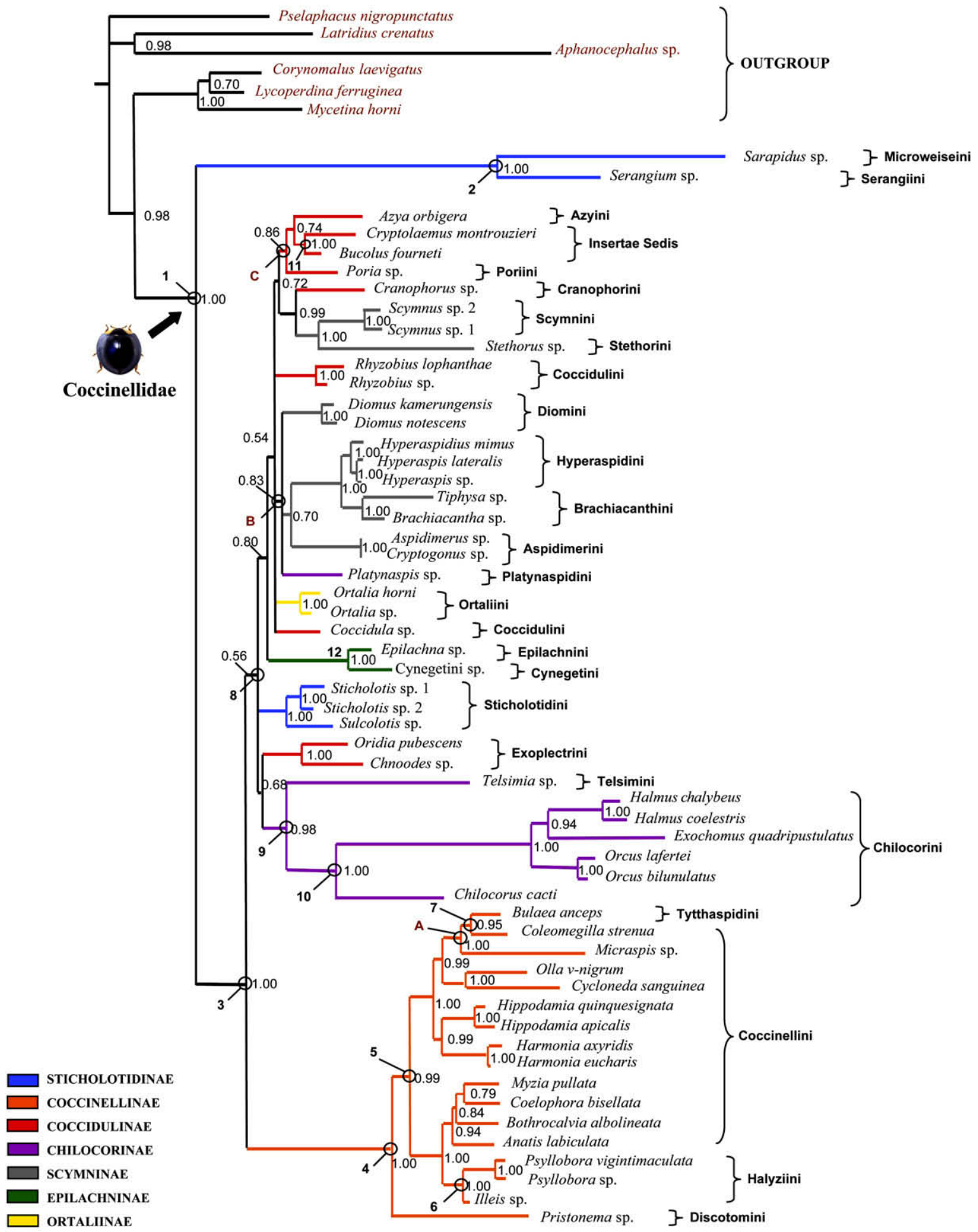

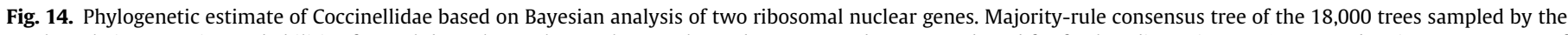

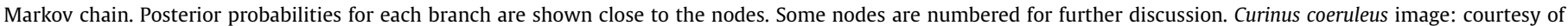
Guillermo González, www.coccinellidae.cl.

the Coccinellidae (Ślipiński et al., 2005). A similar modification is observed in members of the sticholotidine tribe Shirozuellini (e.g., Ghanius). Our study suggests that the lateral expansion of the clypeus has evolved at least twice within Coccinellidae. The tribe Chilocorini is supported as monophyletic [Node $10, \mathrm{BS}=52$, $\mathrm{BR}=5, \mathrm{PP}=1.00]$.

Our analysis supports the sister group relationship between Cryptolaemus and Bucolus suggested by Kovář (1996) [Node 11, 


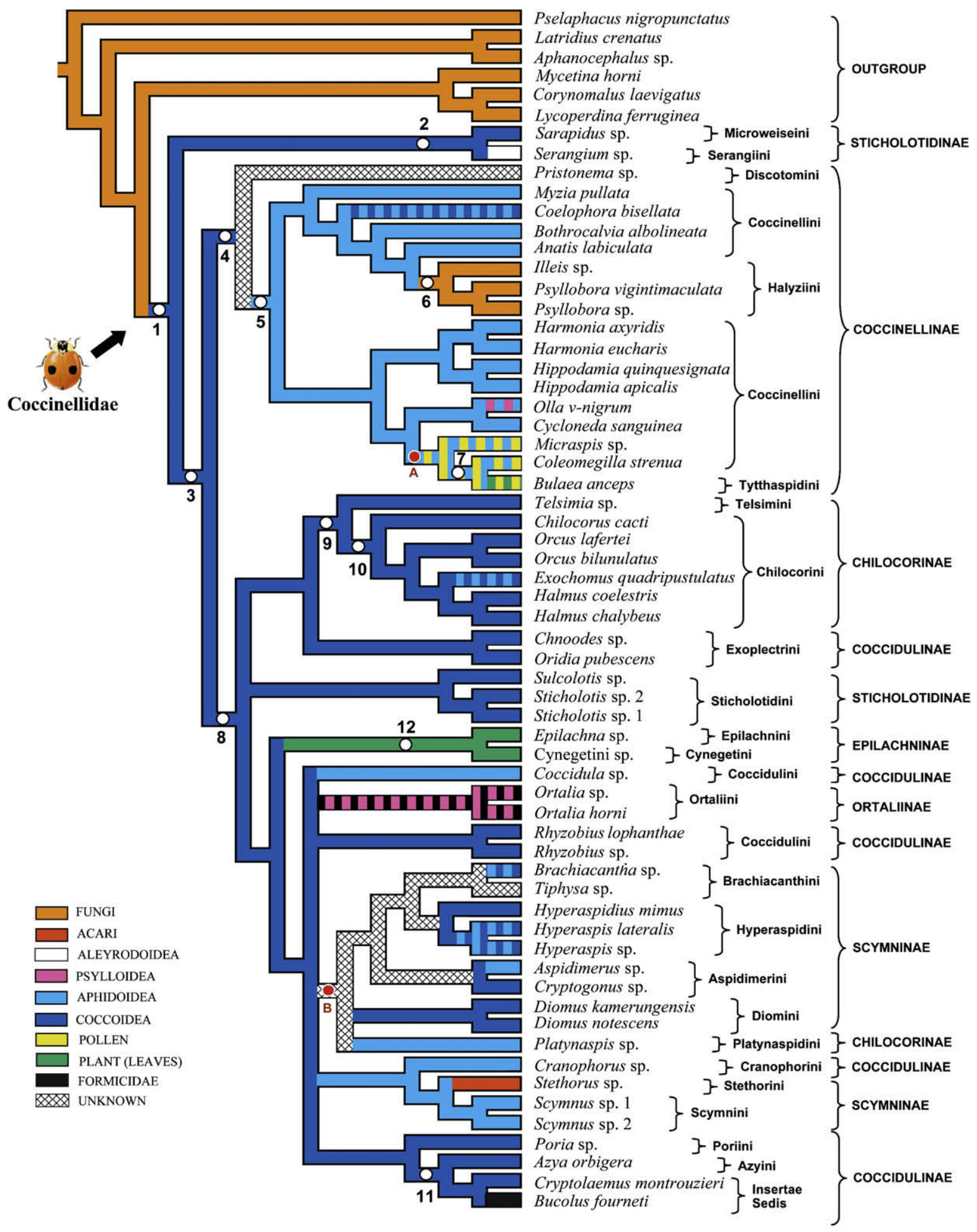

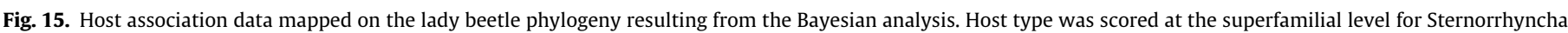

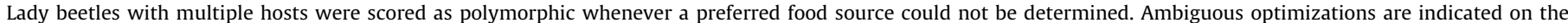
nodes. Adalia bipuncata image: courtesy of Guillermo González, www.coccinellidae.cl.

$\mathrm{BS}=66, \mathrm{BR}=4, \mathrm{PP}=1.00$ ]. It is interesting that among the various authors who distinguished the subfamilies Coccidulinae and Scymninae (sensu Sasaji), all except Kovář placed Cryptolaemus in Scymninae. We suspect this may be based in part on the eye-catching orange and black color pattern and oval shape that make members of
Cryptolaemus evoke a typical, if rather oversized, Scymnus. Antennal length is the first character used by Sasaji to distinguish the scymnine and cocciduline lineages, and by that single criterion (not to mention numerous other inconsistencies) the long, loosely articulated antenna of Cryptolaemus would disqualify it as a scymnine. 


\subsection{Food preference evolution}

\subsubsection{Coccidophagy: the ancestral condition}

With the exception of Coccinellidae, the C.S. is primarily mycophagous. Although there are rare instances of predation known within the Series (e.g., Saula and Bothriderinae), those taxa have never been recovered as close relatives of Coccinellidae and thus they appear to have evolved the trait independently. Higher-level phylogenetic studies (Hunt et al., 2007; Robertson et al., 2008) have recovered Coccinellidae emerging from within mycophagous clades. Therefore, the ancestors of modern Coccinellidae made a transition from mycophagy to predation, specifically coccidophagy, according to these findings (Fig. 15).

Scales are the primary prey of most species of Chilocorinae, Coccidulinae, Scymninae and Sticholotidinae (Table 1 and Fig. 15). According to our analyses, all exclusive scale-feeders are either in clades that have retained the ancestral state of coccidophagy or in clades that are ambiguous for feeding behavior at their basal node. None of the coccinellid taxa included in the current study represents an unambiguous reversal to exclusive coccidophagy from some other type of feeding behavior. In Coelophora bisellata Mulsant (Coccinellinae) scale-feeding has reappeared from an aphidophagous condition; however this species is not exclusively coccidophagous. The major transition to herbivory seen in Epilachnini is derived from scale-feeding (Fig. 15). Similarly, predation on Aphidoidea, Aleyrodoidea, Acari, and Formicidae each represent direct transitions from the ancestral scale-feeding condition or from an ambiguous condition. In our analyses, there is no evidence for an evolutionary stepping stone bridging the transition from coccidophagy to these other feeding behaviors.

\subsubsection{Aphidophagy}

Aphids have been documented as the primary food source for most members of the subfamily Coccinellinae (Ślipiński, 2007). Unfortunately, there are no available host data for the entire tribe Discotomini, so no food preference could be assigned for Pristonema sp., which is positioned as the sister taxon to the clade comprising the rest of Coccinellinae. As a result, the condition for the basal node of the subfamily is unclear. However, our analysis supports aphid-feeding as the ancestral condition for the node subtending the rest of this subfamily (Node 5, Fig. 15).

In addition to the widespread aphid-feeding observed in Coccinellini, exclusive aphidophagy appears in Coccidulini (in Coccidula), Aspidimerini (in Aspidimerus), Platynaspidini (all spp.), and Scymnini (in Scymnus) (Table 1 and Fig. 15). Interestingly, Aspidimerini and Platynaspidini appear nested in an otherwise scymnine clade that includes the tribes Brachiacanthini and Hyperaspidini (Node B, Figs. 14 and 15), each of which includes taxa that are polymorphic for coccidophagy/aphidophagy (Table 1 and Fig. 15). Clearly, there is an underlying tendency toward aphidophagy in this clade.

Some of the phylogenetic findings of this study contradict the current classification of Coccinellidae, yet are consistent with known food preference patterns. The genus Platynaspis (and perhaps the whole tribe Platynaspidini) does not form a monophyletic group with the rest of Chilocorinae. Platynaspidini (here represented by Platynaspis sp.) is the only member of Chilocorinae that does not feed on scales, so its placement in a clade of tribes (Aspidimerini, Hyperaspidini, and Brachiacanthini) with aphidfeeding tendencies is not surprising. In fact, a close relationship between Platynaspidini and Aspidimerini was suggested by Sasaji (1971b), who stated "The Aspidimerini are exactly similar to the Platynaspidini not only in adults but also in larvae. If these structural similarity [sic] were not caused by a secondary convergence, both tribes should be treated in a single phyletic stock."

\subsubsection{Phytophagy (leaf-feeding)}

Our analysis supports two independent shifts to phytophagy. All members of the subfamily Epilachninae feed on plant leaves (Hodek, 1996) and have completely abandoned carnivory. This is the only example of a major transition to strict phytophagy within the entire Cerylonid Series. According to our analysis, the leaf-feeding condition observed in Epilachninae evolved from the ancestral scale-feeding condition.

The genus Bulaea (Tytthaspidini) also includes phytophagous species and represents an independent shift to phytophagy according to our study (Fig. 15). B. lichatschovi is known to eat leaves (Savoiskaya, 1970), as well as pollen (Capra, 1947; Savoiskaya, 1983), but unlike members of Epilachninae, the adults will consume aphids under laboratory conditions (N.J.V., unpublished data). The ancestral state in the transition to phytophagy seen in Bulaea is ambiguous, but was likely aphidophagy, pollinivory, or both. The mandible of adult Bulaea shows little change from the standard aphidophagous type, unlike the highly elaborated biting and grinding surfaces found in the epilachnine mandible (Samways et al., 1997).

According to our hypothesis, the phytophagy observed in B. anceps is nested in a predaceous/pollinivorous clade (Node A) that includes the genera Coleomegilla and Micraspis (Coccinellini). Although adults and larvae of Coleomegilla and Micraspis are primarily predaceous, both genera have a very diverse diet and are among the few predators known to consume substantial quantities of plant material (Pathak and Khan, 1994; Moser et al., 2008). Thus, the relationships supported by our hypothesis (Node A, Fig. 15) are consistent with the food preferences observed in this group, even though they contradict the current classification system.

\subsubsection{Phytophagy (pollen-feeding)}

Pollen is an important alternative food source for many lady beetles regardless of their primary trophic relations, but it has been identified as an essential food for relatively few taxa (Lundgren, 2009a). It seems that a strict pollen diet does not provide adults with sufficient nutrients to promote reproductive behavior and egg maturation in most predatory species (Lundgren, 2009a; Majerus, 1994). Pollinivory may present other challenges to larvae. Some natural environments may not provide adequate free water to complement a dry, powdery diet. Also, in many species the larvae use extra-oral digestion (Hagen, 1962), which entails injecting their prey with hydrolytic enzymes and then sucking out the liquefied body contents. In these taxa the structure of the mouthparts (particularly the prostheca and mandibular dentition) (Samways et al., 1997) may be poorly configured for harvesting and ingesting dry particulate foods.

Although we are not aware of any strict pollinivores in the family Coccinellidae, some of the strongest tendencies in this direction are found among species belonging to node A (Fig. 15). Pollen has been identified as one of the preferred foods for the phytophagous genus Bulaea (Tytthaspidini) (Samways et al., 1997). In addition, the predatory genera Coleomegilla and Micraspis feed extensively on pollen (e.g., Britton, 1914; Putman, 1964; Benton and Crump, 1981; Turner and Hawkeswood, 2003; Omkar, 2006; Lundgren et al., 2004, 2005; Lundgren, 2009a), and are capable of completing their larval development on pollen alone (Smith, 1960; Shepard and Rapusas, 1989; Lundgren and Wiedenmann, 2004). Although classically divided into two distinct tribes, the three exemplar genera in this clade share a number of attributes, including a pollenrich diet, a strong tendency toward polyphagy, and the ability to successfully complete their life cycle in the absence of prey items. Thus, our findings suggest an interesting pattern where polyphagy serves as a stepping stone toward a more specialized arthropodfree diet in which pollen plays a critical role. These phylogenetic 
findings, despite contradicting the current classification, are consistent with the known feeding data for these taxa.

In reality, the terms "predation" and "phytophagy" do not represent absolute categories for coccinellids. Species in the primarily predaceous genera Micraspis and Coleomegilla are known to feed on leaves (Pathak and Khan, 1994; Moser et al., 2008) in addition to pollen during larval development. Similarly, although members of Tytthaspidini have specialized in mycophagy (i.e., Tytthaspis) and phytophagy (i.e., Bulaea), they are known to feed on some insects and mites (Ricci, 1982; N.J.V., unpublished data). The ability for larvae to cope with a dry pollen diet appears to be a significant development in this particular group of lady beetles.

\subsubsection{Mycophagy}

The evolution of the lady beetles seems to be closely associated with fungus feeding. It has been suggested that the preference for Sternorrhyncha might be a consequence of a previous diet on sooty mold that normally grows on honeydew produced by these hemipterans (see Leschen, 2000). Indeed, it appears that there is not a general physiological constraint against fungus consumption in lady beetles, since the use of conidia and spores by adult coccinellids is widespread (e.g., Fig. 9) (Hagen, 1962; Lundgren, 2009b). However, only members of the tribe Halyziini and the genus Tytthaspis (Tytthaspidini) are regarded as fungus specialists (Sutherland and Parrella, 2009). In addition to having morphological adaptations of their mouthparts (Samways et al., 1997), these taxa are unique among lady beetles for having mycophagous larvae (Hodek, 1973; Gordon, 1985; Samways et al., 1997; Sutherland and Parrella, 2009).

Although this study does not include an exemplar of Tytthaspis, it includes another member of Tytthaspidini, B. anceps. Assuming that Tytthaspidini is monophyletic, our findings would suggest that at least two independent shifts toward mycophagy have occurred in Coccinellidae. The mycophagous condition observed in Tytthaspis was derived from a polyphagous condition (Node A, Fig. 15). It should be noted that some Tytthaspis species have not completely abandoned predation, as mites and thrips have been found among the gut contents of $T$. sedecimpunctata (Ricci, 1982).

In contrast, Halyziini seems to be derived from a group of coccinellines with more normal predatory habits than the relatives of Tytthaspidini, but in reality not much is known about the actual prey preferences of these related taxa. Species of Anatis, for example, are not commonly found on low-growing herbs and grasses where their feeding behaviors could be easily scrutinized, but occur in the crowns of mature conifers and broad-leaved trees (Hodek, 1996). They are apparently habitat specialists, and although they are considered aphidophagous, they have been recorded on numerous other prey and alternative foods (Majerus, 1994; McKenzie, 1936). Members of the genus Myzia also are considered arboreal aphidophages, yet they seem to require prey from a select group of pine-feeding aphids in order to induce copulation and oviposition (Majerus, 1994). Clearly our understanding of the trophic requirements of this group is not comprehensive, and a more complete understanding would lend further insights into the transition from predatory to mycophagous habits within this clade.

\subsubsection{Current limitations and future directions}

In this study, we acknowledge numerous shortcomings both in our taxon sampling and methodologies. We have under-represented certain geographical areas (e.g., Africa and Asia), some habitats (e.g., swamplands and upper canopies of tropical rain forests), and certain clades (e.g., the basal taxa (Sticholotidinae, in part = Microweiseinae, sensu Ślipiński), and the phytophagous subfamily Epilachninae). It would be desirable to expand our taxon sampling to get a more comprehensive representation of lady beetle diversity. This is particularly important because our under- standing of the phylogenetic relationships of lady beetles is still rudimentary, and some of the recognized higher-level taxonomic categories for which we obtained exemplars may be largely artificial.

In presenting the evolution of feeding preferences we defined food categories taxonomically (e.g., Aphidoidea and Psylloidea). However, it is not clear that taxonomic classification is the most important criterion for determining trophic relations. In predatory species, for example, it may be that prey mobility, surface features (e.g., cuticular waxes and degree of sclerotization), or seasonal availability are of equal importance (Weber and Lundgren, 2009). Some lady beetles have very clear and narrowly defined feeding preferences, but for others the host plant or habitat may largely determine which prey species are consumed (Weber and Lundgren, 2009). For example, both Naemia seriata and Anatis mali (Say) feed on prey from various ordinal groups, but the former is restricted to grassy saltmarsh habitats, and the latter is nearly always found in the crowns of mature conifers. Even our decision to focus on essential foods may be flawed, since our preliminary results suggest the important role played by supplemental foods in allowing polyphagous species to begin to exploit new trophic niches.

Perhaps one of the greatest difficulties has been in assigning essential food preferences to our exemplar taxa. When possible, we have tried to represent the food choices of the actual species used in the investigation, but where no information was available for a particular genus or species, we assigned the most commonly recorded essential foods of related taxa. In a few cases the trophic relations of an entire genus or tribe were unknown or equivocal. Even for the better documented cases, we have been forced to rely on previously published records and lists reporting laboratory feeding studies, field observations, gut dissections, or merely casual observations of prey/host associations. We cannot determine which food items are essential for reproduction and development without laboratory studies. On the other hand, the results of laboratory feeding trials may misrepresent the actual foods available in the natural habitat and/or fail to realistically duplicate the normal context in which these foods are found (Weber and Lundgren, 2009). For example, many lady beetles do exceptionally well on processed moth eggs which have been sterilized to prevent hatching, removed from the ovipositional substrate, cleaned of obstructing debris, such as scales and webbing, and offered in unnatural densities. With these biases in mind, we sorted through available records to determine which items most likely represented the natural essential foods for the included taxa.

The two ribosomal nuclear genes used in this study proved to be of limited utility in resolving relationships among some of the main lineages in the family. The inclusion of additional genes and morphological data should contribute to a more robust phylogenetic hypothesis. Nevertheless, our analyses generally recovered generic and supergeneric groupings that historically were recognized and supported by morphological data. Where our results suggested novel relationships (e.g., the position of Cryptolaemus or Tytthaspidini), the findings are supported by morphological traits or published food preference data. Overall, we feel that the use of these molecular data to map the evolution of lady beetle feeding preferences is a significant step toward a better understanding of this interesting topic.

\section{Acknowledgments}

We thank the colleagues who supplied valuable specimens for this study, including James Zahniser, Jimmy Miró, Floyd Shockley, James A. Robertson, Nathan Lord, Andrew Cline, Alexey K. Tishechkin, Gavin Svenson, Steve Cameron, Karl Jarvis, Sean Taylor, Alison Whiting, Hong Pang, J. Poorani, Richard A.B. Leschen, and Tomas 
Cekalovic. Meredith Blackwell and Emory G. Simmons provided identifications of the fungal components in the coccinellid gut content images illustrated in Fig. 9. We thank John Brown, Jonathon Lundgren, Allen Norrbom, Floyd Shockley, and Donald Weber for providing helpful comments and corrections on earlier versions of the manuscript.

This work was supported by N.S.F. PEET Grant DEB-0329115 (to J.V.M., K.B.M., and M.F.W.) and N.S.F. AToL Grant EF-0531665 (to M.F.W. and subcontract to J.V.M.). Additional support was provided by the Department of Entomology and the H.H. Ross Memorial Fund at The University of Georgia. The senior author thanks all members of the McHugh Lab and Whiting Lab for their assistance with various phases of the project.

\section{References}

Afroze, S., Uddin, S., 1998. Bioecology of Synia melanaria Mulsant (Coleoptera: Coccinellidae) predating on Coptosoma ostensum Distant. Journal of Entomological Research 22, 329-336.

Almeida, L.M., Carvalho, R.C.Z., 1996. A new species of Azya Mulsant from Brazil (Coleoptera: Coccinellidae) feeding on Pulvinaria paranaensis Hempel (Hemiptera: Coccidae) on Ilex paraguariensis St. Hil. (Aquafoliaceae). Revista Brasileira de Entomologia 13, 643-645.

Al-Zyoud, F. Sengonca, C., 2004. Prey consumption preferences of Serangium parcesetosum Sicard (Coleoptera: Coccinellidae) for different prey stages, species and parasitized prey. Journal of Pest Science 77, 197-204.

Anderson, J.M.E., 1981. Biology and distribution of Scymnodes lividigaster (Mulsant) and Leptothea galbula (Mulsant), Australian ladybirds (Coleoptera: Coccinellidae). Proceedings of the Linnaean Society of New South Wales 105, 1-15.

Anderson, J.M.E., 1982. Seasonal habitat utilization and food of the ladybirds Scymnodes lividigaster and Leptothea galbula Coleoptera Coccinellidae. Australian Journal of Zoology 30, 59-70.

Begum, M.A., Jahan, M., Bari, M.N., Hossain, M.M., Afsana, N., 2002. Potentiality of Micraspis discolor (F.) as a biocontrol agent of Nilaparvata lugens (Stal). Journal of Biological Sciences 2, 630-632.

Benton, A.H., Crump, A.J., 1981. Observations on the spring and summer behavior of the 12-spotted ladybird beetle, Coleomegilla maculata (DeGeer) (Coleoptera: Coccinellidae). Journal of the New York Entomological Society 89, 102-108.

Beyene, Y., Hofsvang, T., Azerefegne, F., 2007. Population dynamics of tef epilachna (Chnootriba similis Thunberg) (Coleoptera: Coccinellidae) in Ethiopia. Crop Protection 26, 1634-1643.

Biddinger, D.J., Weber, D.C., Hull, L.A., 2009. Coccinellidae as predators of mites: Stethorini in biological control. Biological Control 51, 268-283.

Booth, R.G., Cox, M.L., Madge, R.B., 1990. IIE Guides to Insects of Importance to Man 3. Coleoptera. International Institute of Entomology, London.

Bremer, K., 1994. Branch support and tree stability. Cladistics 10, 295-304.

Britton, W.E., 1914. Some common lady beetles of Connecticut. Bulletin of the Connecticut Agricultural Experiment Station 181. 24pp.

Caltagirone, L.E., Doutt, R.L., 1989. The history of the Vedalia Beetle importation into California and its impact on the development of biological control. Annual Review of Entomology 34, 1-16.

Capra, F., 1947. Note sui coccinellidi (Col.). III. La larva ed il regime pollinivoro di Bulaea lichatschovi Hummel. Memorie della Società Entomologica Italiana 26, 80-86.

Carver, M., Gross, F.G., Woodward, T.E., 1991. Hemiptera. In: CSIRO, The Insects of Australia-A Textbook for Students and Research Workers, vol. 1. Melbourne University Press, Melbourne, pp. 429-509.

Chazeau, J., 1981. Données sur la biologie de Coelophora quadrivittata (Col.: Coccinellidae) prédateur de Coccus viridis (Hom.: Coccidae) en NouvelleCalédonie. Entomophaga 26, 301-312.

Chien, C.C., Chou, L.Y., Chang, S.C., 2002. Occurrence and biological control of Aleurodicus dispersus. Formosan Entomology Special Publication 3, 93-109.

Crowder, D.W., 2006. Impact of release rates on the effectiveness of augmentative biological control agents. Journal of Insect Science 7, 1-11.

Crowson, R.A., 1955. The Natural Classification of the Families of Coleoptera Nathaniel Lloyd, London.

Crowson, R.A., 1981. The Biology of the Coleoptera. Academic Press, London.

Dejean, A., Orivel, J., Gibernau, M., 2002. Specialized predation on plataspid heteropterans in a coccinellid beetle: adaptive behavior and responses of prey attended or not by ants. Behavioral Ecology 13, 154-159.

Drea, J.J., Gordon, R.D., 1990. Predators. Coccinellidae. In: Rosen, D. (Ed.), The Armored Scale Insects, their Biology, Natural Enemies, and Control. Elsevier Amsterdam, pp. 19-40.

Duverger, C., 1989. Contribution à l'étude des Hyperaspinae. 1ère note (Coleoptera, Coccinellidae). Bulletin de la Société linnéenne de Bordeaux 17, 143-157.

Duverger, C., 2001. Contribution à la connaissance des Hyperaspinae. 2ème note. Bulletin de la Société linnéenne de Bordeaux 29, 221-228.

Duverger, C., 2003. Phylogénie des Coccinellidae. Bulletin de la Société linnéenne de Bordeaux 31, 57-76.

Edgar, R.C., 2004. MUSCLE: multiple sequence alignment with high accuracy and high throughput. Nucleic Acids Research 32, 1792-1797.
Evans, E.W., 2009. Lady beetles as predators of insects other than Hemiptera. Biological Control 51, 255-267.

Felsenstein, J., 1985. Confidence limits on phylogenies: an approach using the bootstrap. Evolution 39, 783-791.

Finke, D.L., 2005. Predator diversity, habitat complexity and the strength of terrestrial trophic cascades. Doctoral Dissertation. Department of Entomology, University of Maryland, College Park, MD.

Froggatt, W., 1903. Australian ladybird beetles. Agricultural Gazette of New South Wales 13, 895-911.

Fürsch, H., 1967. Familie: Coccinellidae (Marienkäfer). In: Freude, H., Harde, K.W., Lohse, G.A. (Eds.), Die Käfer Mitteleuropas 7. Goecke and Evers, Krefeld, pp. 227-278.

Genecodes, 1999. Sequencher Version 3.1.1. Genecodes Co., Ann Arbor.

Goloboff, P.A., Farris, S.J., Nixon, K.C., 2003. TNT: tree analysis using new technology. Published by the author, Tucumán, Argentina.

Gordon, R.D., 1975. A revision of the Epilachninae of the Western Hemisphere (Coleoptera: Coccinellidae). ARS, USDA Technical Bulletin 1493, Washington, DC.

Gordon, R.D., 1976. The Scymnini (Coleoptera: Coccinellidae) of the United States \& Canada: key to genera and revision of Scymnus, Nephus, and Diomus. Bulletin of the Buffalo Society of Natural Sciences 28, 1-362.

Gordon, R.D., 1977. Classification and phylogeny of the New World Sticholotidinae (Coccinellidae). Coleopterists Bulletin 31, 185-228.

Gordon, R.D., 1985. The Coccinellidae (Coleoptera) of America north of Mexico. Journal of the New York Entomological Society 93, 654-678.

Gordon, R.D., 1994. South American Coccinellidae (Coleoptera). Part III. Definition of Exoplectrinae Crotch, Azyinae Mulsant, and Coccidulinae Crotch; a taxonomic revision of Coccidulini. Revista Brasileira de Entomologia 38, 681-775.

Gordon, R.D., 1999. South American Coccinellidae. (Coleoptera). Part VI. A systematic revision of the South American Diomini, new tribe (Scymninae). Annales Zoologici (Warsazawa) 49, 1-219.

Gordon, R.D., Chapin, E.A., 1983. A revision of the New World species of Stethorus Weise (Coleoptera: Coccinellidae). Transactions of the American Entomological Society 109, 229-276.

Groden, E., Drummond, F.A., Casagrande, R.A., Haynes, D.L., 1990. Coleomegilla maculata (Coleoptera: Coccinellidae): its predation upon the Colorado potato beetle (Coleoptera: Chrysomelidae) and its incidence in potatoes and surrounding crops. Journal of Economic Entomology 83, 1306-1315.

Gullan, P.J., Cook, L.G., 2007. Phylogeny and higher classification of the scale insects (Hemiptera: Sternorrhyncha: Coccoidea). In: Zhang, Z.-Q., Shear, W.A. (Eds.), Linnaeus Tercentenary: Progress in Invertebrate Taxonomy. Zootaxa 1668, 413-425.

Gullan, P.J., Martin, J.H., 2003. Sternorrhyncha (jumping plant-lice, whiteflies, aphids and scale insects). In: Resh, V., Cardé, R. (Eds.), Encyclopedia of Insects. Academic Press, Amsterdam, pp. 1079-1089.

Hagen, K.S., 1962. Biology and ecology of predaceous Coccinellidae. Annual Review of Entomology 7, 289-326.

Hall, D.G. Bennett, F. 1994. Biological control and IPM of sugarcane pests in Florida. In: Bennett, F.D., Rosen, D., Capinera, J.L. (Eds.), Pest Management in the Subtropics: Biological Control: A Florida Perspective, vol. 1. Intercept Ltd., Andover, UK, pp. 297-325.

Harris, R.H.T.P., 1921. A note on Ortalia pallens Mulsant. South African Journal of Science 18, 170-171.

Hippa, H., Koponen, S., Neuvonen, S., 1977. Population dynamics of the form of Galerucella nymphaeae-complex (Coleoptera: Chrysomelidae) living on cloudberry in northern Finland. Reports from the Kevo Subarctic Research Station 13, 36-39.

Hippa, H., Koponen, S., Laine, T., 1978. On the feeding biology of Coccinella heiroglyphica L. (Coleoptera: Coccinellidae). Reports from the Kevo Subarctic Research Station 14, 18-20.

Hippa, H., Koponen, S., Roine, R., 1982. Feeding preference of Coccinella heiroglyphica (Coleoptera: Coccinellidae) for eggs of three chrysomelid beetles. Reports from the Kevo Subarctic Research Station 18, 1-4

Hippa, H., Koponen, S., Roine, R., 1984. Larval growth of Coccinella heiroglyphica (Coleoptera: Coccinellidae) fed on aphids and preimaginal stages of Galerucella sagittariae (Coleoptera: Chrysomelidae). Reports from the Kevo Subarctic Research Station 19, 67-70.

Hirai, Y., Kobayashi, H., Koizumi, T., Katakura, H., 2006. Field-cage experiments on host fidelity in a pair of sympatric phytophagous ladybird beetles. Entomologia Experimentalis et Applicata 118, 129-135.

Hoang, D.N., 1982. Bo Rua Coccinellidae o Viet Nam (Insecta, Coleoptera) Tap 1. Nha Xuat Ban Khoa Hoc Va Ky Thuat, Hanoi.

Hoang, D.N., 1983. Bo Rua Coccinellidae o Viet Nam (Insecta, Coleoptera) Tap 2. Nha Xuat Ban Khoa Hoc Va Ky Thuat, Hanoi.

Hodek, I., 1973. Biology of Coccinellidae. Academia, Prague.

Hodek, I., 1996. Food relations. In: Hodek, I., Honěk, A. (Eds.), Ecology of Coccinellidae. Kluwer Academic Publishers, Dordrecht, pp. 143-238.

Hodek, I., Honěk, A., 1996. Ecology of Coccinellidae. Kluwer Academic Publishers, Dordrecht.

Hodek, I., Honěk, A., 2009. Scale insects, mealybugs, whiteflies and psyllids (Hemiptera, Sternorrhyncha) as prey of ladybirds. Biological Control 51, 232243.

Hunt, T., Bergsten, J., Levkanicova, Z., Papadopoulou, A., St. John, O., Wild, R. Hammond, P., Ahrens, D., Balke, M., Caterino, M., Gómez-Zurita, J., Ribera, I., Barraclough, T., Bocakova, M., Bocak, L., Vogler, A., 2007. A comprehensive phylogeny of beetles reveals the evolutionary origins of a superradiation. Science 318, 1913-1916. 
Iablokoff-Khnzorian, S.M., 1982. Les Coccinelles, Coleoptères-Coccinellidae. Tribu Coccinellini des Regions Palearctique at Orientale. Société Nouvelle des Editions Boubée, Paris.

Igbinosa, B.I., Oigiangbe, N.O., Egbon, N.I., 2007. Insect pests of rain-fed upland rice and their natural enemies in Ekpoma, Edo State, Nigeria. International Journal of Tropical Insect Science 27, 70-77.

Iwata, K., 1932. On the biology of two large lady-birds in Japan. The Transactions of the Kansai Entomological Society 3, 13-26.

Iwata, K., 1965. Supplement on the biology of two large lady-birds in Japan. Niponius-Acta Coleopterologica 2, 57-68.

Jarvis, K.J., Haas, F., Whiting, M.F., 2004. Phylogeny of earwigs (Insecta: Dermaptera) based on molecular and morphological evidence: reconsidering the classification of Dermaptera. Systematic Entomology 30, 1-12.

Kaneko, S., 2007. Larvae of two ladybirds, Phymatosternus lewisii and Scymnus posticalis (Coleoptera: Coccinellidae), exploiting colonies of the brown citrus aphid Toxoptera citricidus (Homoptera: Aphididae) attended by the ant Pristomyrmex pungens (Hymenoptera: Formicidae). Applied Entomology and Zoology 42, 181-187.

Kanervo, V., 1940. Beobachtungen und Versuche zur Ermittlung der Nahrung einiger Coccinelliden. Annales Entomologici Fennici 6, 89-110.

Kanervo, V., 1946. Studien über die natürlichen Feinde des Erlenblattkäfers, Melasoma aenea L. (Coleoptera, Chrysomelidae). Annales Zoologici Societatis Zoologicae-Botanicae Fennicae Vanamo 12, 206pp.

Korschefsky, R., 1931. Pars. 120: Coccinellidae. II. In: Junk, W., Schenkling, S. (Eds.), Coleopterorum Catalogus. W. Junk, Berlin, pp. 225-659.

Kovář, I., 1996. Phylogeny. In: Hodek, I., Honěk, A. (Eds.), Ecology of Coccinellidae. Kluwer Academic Publishers, Dordrecht, pp. 19-31.

Kuznetsov, V.N., 1997. Lady beetles of the Russian Far East, Memoir No. 1. Center for Systematic Entomology. Sandhill Crane Press, Gainesville, FL, USA.

Lawrence, J.F., 1991. Bothrideridae (Cucujoidea). In: Stehr, F.W. (Ed.), Bothrideridae (Cucujoidea). Kendall/Hunt Pub. Co., Dubuque, IA, USA, pp. 477-479.

Lawrence, J.F., Newton, A.F., 1995. Families and subfamilies of Coleoptera (with selected genera, notes, references and data on family-group names). In: Pakaluk, J., Ślipiński, S.A. (Eds.), Biology, Phylogeny and Classification of Coleoptera: Papers Celebrating the 80th Birthday of Roy A. Crowson, vol. 2. Museum i Instytut Zoologii PAN, Warsaw, pp. 779-1006.

Leschen, R.A.B., 2000. Beetles feeding on bugs (Coleoptera, Hemiptera): repeated shifts from mycophagous ancestors. Invertebrate Taxonomy 14, 917-929.

Liu, T.X., Stansly, P.A., 1996. Morphology of Nephaspis oculatus and Delphastus pusillus (Coleoptera: Coccinellidae), predators of Bemisia argentifolii (Homoptera: Aleyrodidae). Proceedings of the Entomological Society of Washington 98, 292-300.

Lu, W., Montgomery, M.E., 2001. Oviposition, development, and feeding of Scymnus (Neopullus) simuanodulus (Coleoptera: Coccinellidae): a predator of Adelges tsugae (Homoptera: Adelgidae). Annals of the Entomological Society of America 94, 64-77.

Lundgren, J.G., 2009a. Relationships of Natural Enemies and Non-prey Foods. Springer International, Dordrecht.

Lundgren, J.G., 2009b. Nutritional aspects of non-prey foods and the life histories of predaceous Coccinellidae. Biological Control 51, 294-305.

Lundgren, J.G., Wiedenmann, R.N., 2004. Nutritional suitability of corn pollen for the predator, Coleomegilla maculata (Coleoptera: Coccinellidae). Journal of Insect Physiology 50, 567-575.

Lundgren, J.G., Huber, A., Wiedenmann, R.N., 2005. Quantification of the consumption of corn pollen by the predator Coleomegilla maculata DeGeer (Coleoptera: Coccinellidae) in an Illinois cornfield. Agricultural and Forest Entomology 7, 1-8.

Lundgren, J.G., Razzak, A.A., Wiedenmann, R.N., 2004. Population responses and food consumption by predators Coleomegilla maculata and Harmonia axyridis (Coleoptera: Coccinellidae) during anthesis in an Illinois cornfield. Environmental Entomology 33, 958-963.

Lundgren, J.G., Hesler, L.S., Tilmon, K.J., Dashiell, K.E., Scott, R., 2009. Direct effects of soybean varietal selection and Aphis glycines-resistant soybeans on natural enemies. Arthropod-Plant Interactions 3, 9-16.

Maddison, W.P., Maddison, D.R., 2003. MacClade, version 4.06. Sinauer Associates, Sunderland, MA.

Majerus, M.E.N., 1994. Ladybirds. The New Naturalist Library. Harper Collins Publishers, London.

Majerus, M., Sloggett, J., Godeau, J., Hemptinne, J.L., 2007. Interactions between ants and aphidophagous and coccidophagous ladybirds. Population Ecology 49, 15-27.

McKenzie, H.L., 1936. An anatomical and systematic study of the genus Anatis of America (Coleoptera: Coccinellidae). University of California Publications in Entomology 6, 263-272.

Michaud, J.P., 2001. Numerical response of Olla v-nigrum (Coleoptera: Coccinellidae) to infestations of Asian citrus psyllid (Hemiptera: Psyllidae), in Florida. Florida Entomologist 84, 608-612.

Mondal, S., Ray, R., Ghorai, M., 2003. Observation on the destruction of Piper betel plant by Eumorphus quadriguttatus (Coleoptera: Endomychidae). Bionotes 5, 51.

Moser, S.E., Harwood, J.D., Obrycki, J., 2008. Larval feeding on bt hybrid and non-bt corn seedlings by Harmonia axyridis (Coleoptera: Coccinellidae) and Coleomegilla maculata (Coleoptera: Coccinellidae). Environmental Entomology 37, 525-533.

Mulsant, M.E., 1846. Histoire Naturelle des Coléoptères de France. SulcicollesSécuripalpes. Maison, Paris.

Mulsant, M.E., 1850. Species des Coléoptères Trimcres Sécuripalpes. Annales des Sciencies Physiques et Naturelles, d'Agriculture et d'Industrie, publiées par la Société nationale d'Agriculture, etc., de Lyon, Deuxicme Série, 2.
Obrycki, J.J., Harwood, J.D., Kring, T.J., O'Neil, R.J., 2009. Aphidophagy by Coccinellidae: application of biological control in agroecosystems. Biological Control 51, 244-254.

Omkar, 2006. Suitability of different foods for a generalist ladybird, Micraspis discolor (Coleoptera: Coccinellidae). International Journal of Tropical Insect Science 26, 35-40.

Pakaluk, J., Ślipiński, S.A., 1990. Review of Eupsilobiinae (Coleoptera: Endomychidae) with descriptions of new genera and species from South America. Review Suisse de Zoologie 97, 705-728.

Pakaluk, J., Ślipiński, S.A., Lawrence, J.F., 1994. Current classification and familygroup names in Cucujoidea (Coleoptera). Genus 5, 223-268.

Pang, X., Mao, J., 1979. Economic Insect Fauna of China-Coleoptera: Coccinellidae. II. Science Press, Beijing.

Pathak, M.D., Khan, Z.R., 1994. Insect Pests of Rice. International Rice Research Institute and ICIPE, Los Baños, Laguna, Philippines.

Pemberton, R.W., Vandenberg, N.J., 1993. Extrafloral nectar feeding by ladybird beetles (Coleoptera: Coccinellidae). Proceedings of the Entomological Society of Washington 95, 139-151.

Poorani, J., 2001. A review of the genus Pseudaspidimerus Kapur (Coleoptera: Coccinellidae) of the Indian region, with description of a new species. Oriental Insects 35, 299-310.

Poorani, J., Ślipiński, S.A., Booth, R., 2008. A revision of the genus Synona Pope (Coleoptera: Coccinellidae, Coccinellini). Annales Zoologici 58, 350-362.

Posada, D., Crandall, K.A., 1998. Modeltest: testing the model of DNA substitution. Bioinformatics $14,817-818$

Pope, R.D., 1989. A revision of the Australian Coccinellidae (Coleoptera). Part 1. Subfamily Coccinellinae. Invertebrate Taxonomy 2, 633-735.

Pope, R.D., Lawrence, J.F., 1990. A review of Scymnodes Blackburn, with the description of a new Australian species and its larva (Coleoptera: Coccinellidae). Systematic Entomology 15, 241-252.

Putman, W.L., 1957. Laboratory studies on the food of some coccinellids (Coleoptera) found in Ontario peach orchards. The Canadian Entomologist 89 572-579.

Putman, W.L., 1964. Occurrence and food of some coccinellids (Coleoptera) in Ontario peach orchards. The Canadian Entomologist 96, 1149-1155.

Redtenbacher, L., 1844. Tetamen dispositionis generum et specierum Coleopterorum Pseudotrimeorum. Archiducatus Austriae, Vienna.

Ricci, C., 1982. Sulla constituzione e funzione delle mandible delle mandiboile delle larvae di Tytthaspis sedecempunctata (L.) e Tytthaspis trilineata (Weise). Frustula Entomologica 3, 205-212.

Ricci, C., 1986. Food strategy of Tytthaspis sedecimpunctata (L.) in different habitats In: Hodek, I. (Ed.), Ecology of Aphidophaga. Proceedings of a Symposium held at Zvíkovské Podhradí. Academia, Prague, pp. 211-216.

Ricci, C., Fiori, G., Colazza, S., 1983. Regime alimentare dell'adulto di Tytthaspis sedecimpunctata (L.) (Coleoptera: Coccinellidae) in ambiente a influenza antropica primaria: prato polifita. In: Proceedings XIII Congresso Nazionale Italiano di Entomologia, Instituto di Entomologia Agraria e Apicoltura, Università di Torino, Turín, pp. 691-697.

Robertson, J.A., Whiting, M.F., McHugh, J.V., 2008. Searching for natural lineages within the Cerylonid Series (Coleoptera: Cucujoidea). Molecular Phylogenetics and Evolution 46, 193-205.

Ronquist, F., Huelsenbeck, J.P., 2003. MrBayes 3: Bayesian phylogenetic inference under mixed models. Bioinformatics 19, 1572-1574.

Samways, M.J., Osborn, R., Saunders, T.L., 1997. Mandible form relative to the main food type in ladybirds (Coleoptera: Coccinellidae). Biocontrol Science and Technology 7, 275-286.

Sasaji, H., 1968. Phylogeny of the family Coccinellidae (Coleoptera). Etizenia Occasional Publications of the Biological Laboratory, Fukui University 35, 1-37.

Sasaji, H., 1971a. Fauna Japonica. Coccinellidae (Insecta: Coleoptera). Academic Press of Japan, Keigaku Publishing, Tokyo.

Sasaji, H., 1971b. Phylogenetic positions of some remarkable genera of the Coccinellidae (Coleoptera), with an attempt of the numerical methods. Memoirs of the Faculty of Education Fukui University, Series II (Natural Science) $21,55-73$.

Sasaji, H., 1978. On the larva of a predaceous endomychid, Saula japonica Gorham (Coleoptera). Kontyu 46, 24-28.

Savoiskaya, G.I., 1970. Coccinellids of the Alma-Ata reserve. Trudy Alma-Atinskogo gosudarstvennogo Zapovednika 9, 163-187.

Savoiskaya, G.I., 1983. Larvae of coccinellids (Coleoptera, Coccinellidae) of the fauna of the USSR. Zoologicheski Institut, Leningrad.

Seagraves, M.P., 2009. Lady beetle oviposition behavior in response to the trophic environment. Biological Control 51, 313-322.

Sebolt, D.C., Landis, D.A., 2004. Arthropod predators of Galerucella calmariensis L. (Coleoptera: Chrysomelidae): an assessment of biotic interference Environmental Entomology 33, 356-361.

Shepard, B.M., Rapusas, H.R., 1989. Life cycle of Micraspis sp. on brown planthopper (BPH) and rice pollen. International Rice Research Newsletter 14, 40.

Simmons, A.M., Legaspi, J.C., Legaspi, B.C., 2008. Responses of Delphastus catalinae (Coleoptera: Coccinellidae), a predator of whiteflies (Hemiptera: Aleyrodidae) to relative humidity: oviposition, hatch, and immature survival. Annals of the Entomological Society of America 101, 378-383.

Ślipiński, A., 2007. Australian ladybird beetles (Coleoptera: Coccinellidae): their biology and classification. Australian Biological Resources Study, Canberra.

Ślipiński, A., Burckhardt, D., 2006. Revision of the Australian Coccinellidae (Coccinellidae). Part 5. Tribe Serangiini. Annales Zoologici (Warszawa) 56 37-58. 
J.A. Giorgi et al./Biological Control 51 (2009) 215-231

231

Ślipiński, A., Giorgi, J.A., 2006. Revision of the Australian Coccinellidae (Coleoptera). Part 6. Tribe Chilocorini. Annales Zoologici (Warszawa) 56, 265-304.

Ślipiński, S.A., Pakaluk, J., 1991. Problems in the classification of the cerylonid series of Cucujoidea. In: Zunino, M., Belles, X., Blas, M. (Eds.), Advances in Coleopterology. European Association of Coleopterology, Barcelona, pp. 79-88.

Ślipiński, A.Pang, H., Pope, R.D., 2005. Revision of the Australian Coccinellidae (Coccinellidae). Part 4. Tribe Telsimini. Annales Zoologici (Warszawa) 55, 243-269.

Sloggett, J.J., Majerus, M., 2000. Habitat preferences and diet in the predatory Coccinellidae (Coleoptera): an evolutionary perspective. Biological Journal of the Linnaean Society 70, 63-88.

Smith, B.C., 1960. A technique for rearing coccinellid beetles on dry foods, and influence of various pollens on the development of Coleomegilla maculata Timb (Coleoptera: Coccinellidae). Canadian Journal of Zoology 38, 1047-1049.

Sutherland, A.M., Parrella, M.P., 2009. Mycophagy in Coccinellidae: review and synthesis. Biological Control 51, 284-293.

Takagi, M., 1999. Perspective of practical biological control and population theories. Researches on Population Ecology 41, 121-126.

Takagi, M., Ogata, T., 1985. Seasonal prevalence of Saula japonica Gorham (Coleoptera: Endomycidae), a predator of Unaspis yanonensis (Kuwana) in a citrus orchard where Coccobius fulvus (Compere et Annecke) was released. Proceedings of the Association for Plant Protection Kyushu 31, 199-201.

Takahashi, R., 1921. Aphididae of Formosa. Part IV. Agricultural Experiment Station Government of Formosa Report 20, 1-97.

Tomaszewska, K.W., 2000. Morphology, phylogeny and classification of adult Endomychidae (Coleoptera: Cucujoidea). Annales Zoologici (Warszawa) 50, 449-558.

Tomaszewska, K.W., 2005. Phylogeny and generic classification of the subfamily Lycoperdininae with a re-analysis of the family Endomychidae (Coleoptera: Cucujoidea). Annales Zoologici (Warszawa), 1-172.
Turian, G., 1969. Coccinelles micromycetophages. Mitteilungen der Schweizerischen Entomologischen Gesellschaft 42, 52-57.

Turner, J.R., Hawkeswood, T.J., 2003. Further observations on the feeding of adult Micraspis frenata (Erichson, 1842) (Coleoptera: Coccinellidae) on the pollen of grasses (Poaceae) in New South Wales, Australia. Calodema 1, 22-23.

Vandenberg, N.J., 2002. Coccinellidae Latreille 1807. In: Arnett, R.H., Jr., Thomas, M.C., Skelley, P.E., Frank, J.H. (Eds.), American Beetles. CRC Press, Boca Raton, pp. 371-389.

Vandenberg, N.J., Perez-Gelabert, D.E., 2007. Redescription of the Hispaniolan ladybird genus Bura Mulsant (Coleoptera: Coccinellidae) and justification for its transfer from Coccidulinae to Sticholotidinae. Zootaxa 1586, 39-46.

Weber, D.C., Lundgren, J.G., 2009. Assessing the trophic ecology of the Coccinellidae: Their roles as predators and as prey. Biological Control 51, 199214.

Wen, H.C., 1995. Bionomics and control of spiraling whitefly (Aleurodicus disperses Russell) in Taiwan. Doctoral Dissertation. Graduate Institute of Plant Pathology and Entomology, National Taiwan University.

Wheeler Jr., A.G., Jubb Jr., G.L., 1979. Scymnus cervicalis Mulsant, a predator of grape phylloxera, with notes on S. Brullei Mulsant as a predator of woolly aphids on elm (Coleoptera: Coccinellidae). Coleopterists Bulletin 33, 199-204.

Whitehead, D.R., Duffield, R.M., 1982. An unusual specialized predator prey association (Coleoptera: Coccinellidae, Chrysomelidae): failure of a chemical defense and possible practical application. Coleopterists Bulletin 36, 96-97.

Whiting, M.F., 2002. Mecoptera is paraphyletic: multiple genes and phylogeny of Mecoptera and Siphonaptera. Zoologica Scripta 31, 93-104.

Yu, G., 1994. Cladistic analyses of the Coccinellidae (Coleoptera). Entomologica Sinica 1, 17-30. 